\title{
OBCE NARODY \\ W KSIĘDZE SOFONIASZA (SO 2,4-15)
}

Druga sekcja Księgi Sofoniasza $(2,4-15)$ rozpoczyna się od ponownej zachęty $(2,1-3)$ opartej na wyroczniach przeciw obcym narodom. Motywacja dotycząca wezwania do nawrócenia Judy wynika z ogłoszenia nadchodzących nieszczęść dla obcych narodów, z którymi Juda graniczył. Z jednej strony kara, która ma spaść na obce narody, ma uświadomić Judejczykom, że nie zdołają uniknąć słusznej kary. Z drugiej jednak strony, błogosławieństwa, jakimi darzony jest naród judejski, powinny zainspirować go do sprawiedliwego postępowania wobec Boga. Lecz z jeszcze innej, trzeciej, perspektywy, uczestnictwo pogan w błogosławieństwach JHWH winno doprowadzić Izrael do zazdrości, która będzie ich prowadziła do jedynego, prawdziwego i żyjącego Boga. Wszystkie te elementy odnajdujemy w naszej sekcji. Sofoniasz ogłasza zagładę Filistynów na zachodzie (ww. 4-7), Moabu i Ammonu na wschodzie (ww. 8-11), Kusz na południu (w. 12) oraz Asyrii na północy (ww. 13-15). ${ }^{1}$

Porządek wyroczni nie do końca jest jasny. Wymienienie Asyrii na końcu mogło być spowodowane tym, że w czasach Sofoniasza była ona najpotężniejszym z wrogów Judy. Układ krzyżowy, co do kierunków geograficznych, mógł być odwzorowaniem porządku wyroczni Am 1,3-2,16. ${ }^{2}$ Chociaż tam porządek wyroczni podyktowany był raczej wrogością, czasową zgodą, przyjaźnią i pokrewieństwem narodów z Izraelem. Zatem szczegółowe powody porządku tych wyroczni u Sofoniasza są trudne do ustalenia.

O.P. R o b e r $\mathrm{t}$ s o n, The Books of Nahum, Habakkuk and Zephaniah, The New International Commentary on the Old Testament, Grand Rapids 1990, s. 296.

2 Tamże. 


\section{Wyrocznia przeciw Filistynom (So 2,4-7)}

Sekcja dotycząca Filistynów obejmuje wiele danych geograficznych dotyczących zarówno miast Filistei, jak i ludów je zamieszkujących. Nie bez znaczenia są również wzmianki na temat Judy, jednak nie wprost, lecz za pomocą sformułowania „ocaleni z domu Judy” (w. 7). W tym punkcie opracowania omówimy najpierw dane geograficzne dotyczące nazewnictwa Filistei, a następnie przejdziemy do omówienia treści i znaczenia wyroczni.

\section{Dane geograficzne}

W So 2,4 wymienione zostały następujące miejscowości filistyńskie: Gaza, Aszkelon, Aszdod i Ekron. Wszystkie cztery reprezentują całą Filisteę. Podobnie, jak w Am 1,6-8 i Za 9,5-7, nie został wymieniony Gat. ${ }^{3}$

Gaza ('azzāh) jest miastem często wspominanym w Starym Testamencie (zob. np. Rdz 10,19; Pwt 2,23; Joz 10,41; 15,47; Sdz 1,18; 6,4; $1 \mathrm{Krl} 5,4 ; 2 \mathrm{Krl} 18,8 ;$ Jr 25,20; 47,1.5; Am 1,6.7; Za 9,5), a także w starożytnych dokumentach pozabiblijnych. Dawniej było to bogate miasto i ważny ośrodek handlowy, ponieważ miało silnie rozwinięte zaplecze rolnicze, a leżało przy jedynej drodze łączącej Egipt z Syrią i Mezopotamią. Nie dziwi więc fakt, że o kontrolowanie tego bogatego miasta zabiegali starożytni władcy. Tutmozes III (XV w. przed Chr.), a zwłaszcza Seti I (1313-1292 przed Chr.) utrzymywali je pod wpływem Egiptu. W XII w. przed Chr. Gazę i tereny do niej przylegające zajęli Filistyni, który utrzymali się w tym rejonie przez kolejne wieki. Z Joz 15,47 dowiadujemy się, że tereny te miały przypaść w udziale pokoleniu Judy, jednak Filistyni nie ustąpili przed Izraelitami. Poczynając od VIII w. przed Chr. Gaza uznała panowanie kolejno Asyryjczyków (w 734 r. zajmuje ją Tiglat-Pileser III), na krótko Egipcjan (faraon Neko), w reszcie Babilończyków (w 605 r.

3 L. W a 1 ke r, Zephaniah, w: F.E. G a e b e le in (red.), The Expositor's Bible Commentary. Daniel and the Minor Prophets, t. 7, Grand Rapids 1986, s. 552. 
Nabuchodonozor). W późniejszym czasie miasto przeżywało chwile wzlotów i upadków, było burzone i odbudowywane. W czasach rzymskich było jednym z ośrodków kultury hellenistycznej. ${ }^{4}$ Prorocy nieraz występowali przeciw Gazie (zob. Jr 47,1.4-5; Am 1,6-7; So 2,4; Za 9,5). „Umocnione miasto”, o którym czytamy w Księdze Daniela (Dn 11,15), to zapewne właśnie Gaza. Diakon Filip na drodze z Jerozolimy do Gazy spotkał urzędnika egipskiej królowej Kandaki (Dz 8,26) i ochrzcił go. W okresie bizantyjskim (IV/V w. po Chr.) Gaza stała się ważnym ośrodkiem chrześcijańskim. ${ }^{5}$

Aszkelon ('ašq $q^{e} l \bar{l} n$ ), wymieniony także w 2,7, leżał nad morzem, na północ od Gazy. Jego położenie, podobnie jak innych miast nadmorskich, decydowało o tym, że stało się ono przedmiotem zakusów ówczesnych potęg. Przed Filistynami zamieszkiwali go Awwici (zob. Pwt 2,23; Joz 13,3). Około 1280 r. przed Chr. musieli uznać władzę Ramzesa II, a w XII w. przed Chr. zajęli je migrujący z Krety Filistyni, którzy odtąd stali się jego jedynymi władcami. ${ }^{6}$ Bez wątpienia Aszkelon należał do najstarszych, najważniejszych i największych miast Palestyny. Potwierdzenie jego istnienia potwierdzają egipskie teksty złorzeczeń z XIX w. przed Chr., a także w listach z Amarna z XVI w. przed Chr., w których władca miasta zapewnia faraona o swojej lojalności. W czasach Ramzesa II (1279-1213 przed Chr.) przedstawiano je nawet graficznie jako warowną wieżę. W $1229 \mathrm{r}$. przed Chr. zajął je faraon Merneptah. ${ }^{7}$ Według Sdz 1,18 Gaza, Aszkelon i Ekron miały należeć do Judy, jednak nie wiadomo, na ile Jozuemu udało się je zająć, bo wiadomo skądinąd, że Filistyni zatrzymali te miasta (zob. Joz 13,3; 1Sm 6,17; 2Sm 1,20). W swojej historii Aszkelon przeżywał najazdy Asyryjczyków. W 734 r. Tiglat-Pileser III zmusza jego władców do złożenia daniny, a w 703 r.

4 S. Potocki, Księga Sofoniasza. Wstęp, przekład, komentarz, w: S. Ł a c h (red.), Księgi proroków mniejszych. Nahuma, Habakuka, Sofoniasza, Aggeusza, Zachariasza, Malachiasza, Poznań 1968, s. 172.

5 P.C. B o s a k, Leksykon wszystkich miejsc biblijnych, Kraków 2016, s. 345.

6 S. P o t o c k i, Księga Sofoniasza, s. 172.

7 P.C. B o s a k, Leksykon wszystkich miejsc biblijnych, s. 99. 
miasto ponosi klęskę w walce z Sennacherybem, ${ }^{8}$ a jego król, Sidka, zostaje deportowany do Asyrii. W kolejnych latach władcy Asyrii, Asarhaddon (680-669 przed Chr.) i Asurbanipal (668-630/625 przed Chr.), wykorzystywali Aszkelon jako bazę wojskową, co przyczyniło się do znaczne zniszczenia miasta (por. Jr 25,17-20.27-38; 47,5-7; So 2,4-7). W późniejszym czasie Aszkelon należał do Tyru, potem podległy był Machabeuszom, a od 104 r. przed Chr. stał się wolnym miastem. Herodowi Wielkiemu nie udało się wcielić Aszkelonu do swojego państwa, choć stamtąd prawdopodobnie pochodziła jego rodzina, tam się urodził i tam miał swój pałac, który po jego śmierci otrzymała jego siostra, Salome, i w znacznej mierze przyczyniała się do wzbogacenia miasta, wznosząc pałace, świątynie, kolumnady i fontannę, stoę i zakładając ogrody. ${ }^{9}$ Podczas wojny żydowskiej (66-70 r. po Chr.) Aszkelon został zrównany z ziemią. Widziano w tym spełnienie się zapowiedzi prorockich, że Aszkelon ,zmieni się w pustynię" (So 2,4; por. Jr 25,20; 45,5-7; Am 1,8; Za 9,5). ${ }^{10}$

Aszdod ('aše dōd) było to miasto, z grecka zwane Azotos, położone w północnej Judzie, 4 km w głąb lądu od brzegu Morza Śródziemnego i $35 \mathrm{~km}$ na północ od Gazy. Z literatury ugaryckiej wiemy, że Aszdod, Akko i Aszkelon utrzymywały stosunki z Ugarit (Ras Szamra), a więc ich istnienie jako miast jest potwierdzone już w XIV w. przed Chr. ${ }^{11}$ Potomkami pradawnych mieszkańców tego regionu (Gazy, Gat i Aszdod) byli Anakici, którzy później zostali podbici przez Filistynów (Joz 11,22). W XI w. przed Chr. było to jedno z pięciu głównych miast (Aszkelon, Aszdod, Gaza, Gat, Ekron) Pentapolu Filistynów, między Gazą a Jafą (Joz 13,3; 1Sm 6,17). ${ }^{12}$ Miasta, pozostającego pod władzą Filistynów, nie udało się zdobyć Jozuemu (Joz 13,2-3). Znajdowało się w nim ważne sanktuarium

\footnotetext{
8 S. P o t o c k i, Ksiega Sofoniasza, s. 172.

9 J ó z e f F l a w i u s z, Wojna żydowska, tłum. J. R a d o ż y c k i, Poznań 1980,
} s. 1, 21, 422-423.

10 P.C. B o s a k, Leksykon wszystkich miejsc biblijnych, s. 100-101.

11 S.B. Re i d, Aszdod, tłum. M. Woj c i e c how s k i, w: P.J. A c h t e me ie r (red.), Encyklopedia Biblijna, Warszawa 1999, s. 66.

12 P.C. B o s a k, Leksykon wszystkich miejsc biblijnych, s. 97. 
Dagona (1Sm 5,2-5). Informacja, że przypadło ono w udziale Judzie (Joz 15,46-47), świadczy o tym, iż na krótko przeszło w posiadanie Judy, być może za czasów panowania Dawida. Jest to jednak wątpliwa informacja, a samo miasto prawdopodobnie nigdy nie należało ani do Judy, ani do Izraela. Do czasu podboju dokonanego przez Ozjasza (zob. 2Krn 26,6) Aszdod rządziło się samodzielnie. W czasie wojny syro-efraimskiej (734 r. przed Chr.), na prośbę Achaza, króla Judy, przybył w ten rejon Sargon II, władca asyryjski, i zdobył miasto. ${ }^{13}$ Podobny los spotkał je także ze strony faraona Psametyka $(\operatorname{Jr} 25,20)$, który zaatakował, gdy wpływy asyryjskie osłabły. ${ }^{14} \mathrm{~W}$ czasie niewoli babilońskiej Aszdod wydaje się jedynym z tych miast, które skorzystały na spustoszeniu Judy przez Nabuchodonozora. W każdym razie po powrocie w niewoli połowa dzieci tu mieszkających mówiła po aszdocku (Ne 13,23-24; Za 9,6). O przekonaniu mieszkańców Aszdod co do zwierzchnictwa nad obszarem Jerozolimy, świadczą próby przeszkodzenia w jej odbudowie (Ne 4,1-2). ${ }^{15} \mathrm{~W}$ tym też czasie (okres perski) Aszdod stało się stolicą satrapii, do której należała też część Judy w Szefeli i Ekronie. W okresie hellenistycznym nazwa miasta została zmieniona na Azot. Dalsze jego losy były jeszcze bardziej burzliwe, ${ }^{16}$ lecz to nie należy już do okresu historii, którym zajmujemy się w tym opracowaniu.

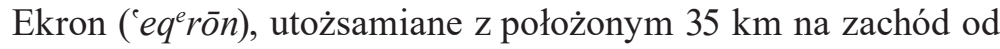
Jerozolimy dzisiejszym Chirbat al-Mukanna. Było to najbardziej wysunięte na północ miasto filistyńskie. Należało do pokolenia Judy (Joz 15,11) albo Dana (Joz 19,43), ale próba przeniesienia do niego Arki Przymierza (1Sm 5,10-12), wskazuje, że przynajmniej wówczas Ekron pozostawał w rękach Filistynów. ${ }^{17}$ Według 1Sm 17,52 mieszkańcy

13 F.V. Re it e r e r, Aszdod, tłum. M. S z c ze pan i a k, w: F. K o g le r, R. Eg g e r - W e n ze 1, M. Er n s, H. W it c z y k (red.), Nowy Leksykon Biblijny, Kielce 2011, s. 44.

14 S.B. R e i d, Aszdod, s. 66-67.

15 F.V. R e it e re r, Aszdod, s. 44.

16 Zob. P.C. B o s a k, Leksykon wszystkich miejsc biblijnych, s. 98-99.

17 S. B o s a k, Księga Sofoniasza, s. 172; S.B. R e i d, Ekron, tłum. M. W oj c i e ch ow sk i, w: P.J. A c h t e m e i e r (red.), Encyklopedia Biblijna, s. 248. 
miasta przyjęli pokonane oddziały filistyńskie, gdy podboje Dawida zmniejszyły znacznie terytorium Filistynów. Groźby proroków wskazują na to, że zarówno w czasach królewskich (Am 1,8 - VIII w. przed Chr.; Jr 25,20 - 600 r. przed Chr.), jak i po niewoli babilońskiej (Za 9,5-7) w mieście tym mieszkali groźni poganie - Filistyni. Siłę oddziaływania i atrakcyjność pogańskich wierzeń widać w tym, że Ochozjasz (853-852 r. przed Chr.), władca Państwa Północnego, oczekiwał większej pomocy od Beelzebuba niż od JHWH (2Krl 1,2-3). ${ }^{18}$ Według tradycji prorockich Eliasz został powołany, aby wystąpić przeciw Beelzebubowi, bóstwu Ekronu, gdy przepowiadał los Ochozjasza (2Krl 1,2-16). Amos zaś $(1,8)$, a także Jeremiasz $(25,20)$ oraz Sofoniasz $(2,4)$ i Zachariasz $(9,5.7)$ potępiali Ekron, który zostanie zniszczony jako siedlisko złych mocy. ${ }^{19}$

Pod koniec X w. przed Chr. miasto zostało podbite przez faraona Szeszonka, a w 712 r. przed Chr. zdobył je dla Asyrii Salmanassar V. Kiedy zaś w VIII w. przed Chr. Ekron przystąpił do powstania Aszkelonu przeciw Asyrii, w 701 r. przed Chr. Sennacheryb dokonał rzezi buntowników i zaanektował miasto. Bardzo możliwe, że północna część kraju Filistynów, w tym Ekron, została zajęta przez Judę za czasów króla Jozjasza (641-609 r. przed Chr.). ${ }^{20}$

W So 2,5 wymieniono następujące nazwy własne powiązane z krajem Filistynów: mieszkańcy morskiego wybrzeża, Keretyci, Kanaan oraz ziemia filistyńska.

„Mieszkańcy morskiego wybrzeża” (jōšbê hebel hajjām), to określenie wskazujące na miejsce aktualnego zamieszkania Filistynów, którym było południowowschodnie wybrzeże Morza Śródziemnego. W tej perykopie spotykamy jeszcze inne, podobne określenia: „,morskie wybrzeże" (hebel hajjām; w. 6) i po prostu „wybrzeże” (hebel; w. 7). Tym razem jednak chodzi o lokalizację geograficzną, a nie o zamieszkującą ją ludność.

18 F.V. Re it e re r, Ekron, tłum. T. S i e m i e n i e c, w: F. K o g l e r, R. Eg g e r - We n z e 1, M. E r n s, H. W i t c z y k (red.), Nowy Leksykon Biblijny, s. 176.

19 S.B. R e i d, Ekron, s. 248.

20 P.C. B o s a k, Leksykon wszystkich miejsc biblijnych, s. 289. 
Keretyci ( $k^{e}$ rētîm), to lud zamieszkujący południową część Palestyny, a dokładniej południowy wschód Filistei. Pierwotnie nazwa ta oznaczała, jak można przypuszczać, naród sąsiadujący z Filistynami.

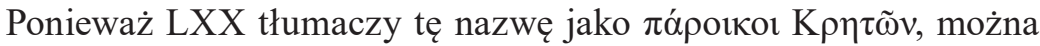
wnioskować, że pierwotnym miejscem ich pochodzenia była Kreta (por. Rdz 10,14), z której przybyli do Palestyny wraz z Filistynami i tutaj stworzyli własny styl życia. ${ }^{21} \mathrm{Z}$ czasem jednak byli utożsamiani z Filistynami (1Sm 30,14; 2Sm 8,18; 15,18; Ez 25,16; So 2,5). ${ }^{22}$ Armia najemników, której dowódca był Benajasz (2Sm 8,18; 1Krn 18,17), rekrutowała się spośród Keretytów i Peletytów (prawdopodobnie inna nazwa Filistynów; zob. 2Sm 15,18; 20,7; $1 \mathrm{Krl} 1,38.44){ }^{23}$

Kanaan ( $\left.k^{e} n a^{\prime} a n\right)$ to pierwotna nazwa Palestyny, ziemi obiecanej przez Boga Abrahamowi i jego potomstwu, Ziemi Świętej (Rdz 11,31; 12,7; 13,15; Wj 6,4), krainy mlekiem i miodem płynącej (Wj 3,8; por. Pwt 8,7-10.12,13), regionu wybrzeża palestyńsko-fenickiego między Morzem Śródziemnym na zachodzie a Pustynią Arabską na wchodzie. ${ }^{24}$ Dokumenty pozabiblijne określają go mianem Kinahni lub Kinahhi. Kanaan więc, w naszym kontekście, jest nazwą terytorium, które przed przybyciem Izraelitów zamieszkiwały plemiona bardzo zróżnicowane etnicznie (por. Rdz 15,18-20). Nazwa ta odnosi się jednak do tych właśnie ludów i określa je jako jedną grupę nie ze względów etnicznych, lecz dlatego, że zamieszkiwały właśnie te tereny. W takim sensie mowa jest o mieszkańcach i królach kananejskich (zob. m.in. Rdz 28,1.6.8; 36,2; Wj 15,15; Sdz 4,2.23). Na takie znaczenie wskazuje również kolejne określenie. ${ }^{25}$

${ }^{21}$ F. Gra d l, Keretyci, tłum. T. S i e m i e n i e c, w: F. K o g l e r, R. Eg ge r- We n z e 1, M. E r n s, H. W i t c z y k (red.), Nowy Leksykon Biblijny, s. 347.

22 S. B o s a k, Księga Sofoniasza, s. 173.

23 F. Gra d 1, Keretyci, s. 347.

24 P.C. B o s a k, Leksykon wszystkich miejsc biblijnych, s. 506. Szerokie omówienie znaczenia tego pojęcia w aspekcie geograficznym, historycznym i biblijnym zob. też R.M. G o o d, Kanaan, Kananejczycy, tłum. M. W o j c i e c how s k i, w: P.J. A c h t e m e i e r (red.), Encyklopedia Biblijna, s. 504-506.

25 S. P o t o c k i, Księga Sofoniasza, s. 173. 
„Ziemia filistyńska” ('erec pelištîm) wiąże się bezpośrednio z nazwą własną $P^{e} l i$ šet $^{e} m$, która dała początek nazwie Palestyna. ${ }^{26}$ „Ziemia filistyńska" to biblijna nazwa terytorium zamieszkanego przez Filistynów. Ich pochodzenie wciąż nie jest pewne. Należy je wiązać z ruchami etnicznymi, do których doszło w basenie Morza Egejskiego pod koniec XIII w. przed Chr. Wówczas, z nieznanych powodów społecznych, politycznych i ekonomicznych, wiele ludów przeniosło się do Grecji, na wyspy Morza Egejskiego i do wschodniej Anatolii. Z tej mieszaniny ludów wyłoniły się tzw. ludy morza, a ich wojenny pochód wschodnim wybrzeżem Morza Śródziemnego położył kres imperium hetyckiemu wraz z państwem-miastem Ugarit. „Ludy morza” dotarły ostatecznie do Fenicji i Palestyny, a nawet do granic Egiptu. Ramzes III ok. 1190 r. przed Chr. walczył z dwoma grupami „ludów morza": Czekerami i Filistynami. Wojna toczona była na lądzie i na morzu. Egipcjanie ostatecznie zwyciężyli, czego dowód mamy w postaci malowideł na ścianach świątyni grobowej Ramzesa III w Tebach. ${ }^{27}$ Po tym zwycięstwie faraon pozwolił Filistynom na osiedlenie się na południowym wybrzeżu palestyńskiej Równiny Nadbrzeżnej, mniej więcej na terenie od dzisiejszego Tel Awiwu po Gazę. W ten sposób ten egejski lud otrzymał nową ojczyznę, a do jego głównych miast należały Gaza, Aszkelon, Gat, Aszdod i Ekron. W późniejszym czasie Filistyni zmieszali się z Kananejczykami i przejęli ich religię oraz kulturę. ${ }^{28} \mathrm{Od}$ Hetytów przejęli umiejętność obróbki żelaza, na co przez długi czas mieli monopol w tamtym rejonie (por. 1Sm 13,19-22). Około X w. przed Chr. mieli pełną władzę na terenie Palestyny, po zachodniej stronie Jordanu. Dopiero powstający Izrael podjął z nimi walkę, a w okresie monarchii dopiero Dawidowi udało się ich pokonać (2Sm 2,50; 8,1; 21, 15-22), ale do walk dochodziło również później $(2 \mathrm{Krl} 18,8) .{ }^{29} \mathrm{Po}$

26 M. Ern s t, Filistyni, tłum. Ł. S i e m i e n i e c, w: F. K o g l e r, R. Eg g e r - We n z e 1, M. Er n s, H. Wi t c z y k (red.), Nowy Leksykon Biblijny, s. 209.

${ }_{27}$ G.L. Mat t i n g ly, Filistyni, tłum. T. M i e s z k ow s k i, w: P.J. A c h t e m e i e r (red.), Encyklopedia Biblijna, s. 301-302.

28 S. P o t o c k i, Księga Sofoniasza, s. 173.

29 M. Er n s t, Filistyni, s. 210. 
najazdach Asyryjczyków, Babilończyków i Persów, a później Ptolemeuszy i Seleucydów, Filistyni, podobnie jak Izrael i Juda, dostali się pod ich panowanie.

\section{Treść i znaczenie wyroczni przeciw Filistynom}

Miasta filistyńskie i mieszkańcy tego regionu zagrożeni są zagładą (w. 4), kraj stanie się pastwiskiem (ww. 5-6). Jednak w zakończeniu tej perykopy mowa jest o ocalałej reszcie Judy, która weźmie w posiadanie ten opuszczony kraj (w. 7). To oczekiwanie może być odzwierciedleniem tendencji charakterystycznych dla okresu reformy Jozjasza, które zakładały nie tylko powrót do zachowania zasad religii jahwistycznej z okresu przedasyryjskiego, lecz także odzyskanie ziem utraconych w czasie asyryjskiej okupacji (2Krl 23). Wyrocznia rozpoczyna się od ogłoszenia wyroku skazującego na miasta filistyńskie, a następnie akcent został przesunięty na pozytywny dla Judy wymiar wyroczni, bowiem to właśnie ocalała reszta owego narodu odziedziczy opustoszałe ziemie. ${ }^{30}$

Już w pierwszym zdaniu cztery miasta filistyńskie zostały ostrzeżone przed czekającą je zagładą: „Bo Gaza zostanie bezludna, a Aszkelon spustoszony, Aszdod w południe wypędzą i Ekron będzie wyrwany z korzeniami” (w. 4). Poszczególne miasta zostały przedstawione według planu geograficznego: od południa na północ: Gaza, Aszkelon, Aszdod i Ekron. Prezentacja jest dość zdawkowa. Pierwsze miasto zostanie bezludne ( $\breve{a z u}$ ûa $\bar{h}$ tihjeh; zob. Iz 17,9; Jr 4,29), drugie spustoszone (liše māmāh; zob. Kpł 26,33; Jr 4,27; 9,10), trzecie wyludnione z powodu wypędzenia ( $j^{e} g \bar{a} r^{e} \stackrel{s}{s} \hat{u} \bar{a} \mathrm{~h} ; \mathrm{zob}$. Ps 78,$55 ; 80,8$; Mi 2,9), czwarte zostanie wykorzenione (té'āqeer ; Koh 3,2). Ta kumulacja i różnorodność terminologii zdaje się wskazywać na całkowitą zagładę miast. Prezentacja nieszczęść, które spotkają pierwsze i ostatnie miasto, została zbudowana na aliteracji: $k \hat{\imath} ' z z \bar{a} h$ 'ăzûbāh i we'ekrôn tée'àqēr. Niektórzy dopatrują się tu nawet budowy

30 R.A. B e n n e t t, The Book of Zephaniah, w: L.E. K e c k (red.), New Interpreter's Bible, t. 7, Nashville 1994-2004, s. 690. 
chiastycznej, ze względu na paronomazję między A-szkelon i A-szdod. ${ }^{31}$ Nieszczęście, które spotyka Aszdod, dokona się „,W samo południe" (baccāhărajim), co przypuszczalnie wskazuje na nieoczekiwaną porażkę w najgorętszej chwili dnia (por. 2Sm 4,5; $1 \mathrm{Krl} 20,16$; $6,4 ; 15,8)$ lub na niespotykaną siłę ataku, który potrwa jedynie pół dnia. $^{32}$

Za pomocą klasycznego hôj wprowadzona została wyrocznia zapowiadająca zagładę Filistynów (w. 5). Terytorium pozostające pod ich kontrolą najpierw zostało określone za pomocą nazw ich głównych miast (w. 4). Teraz określa się je przez odniesienie do pozycji Filistynów wśród narodów ówczesnego świata. Mają oni „wybrzeże morskie" (hebel hajjām), co było zachodnią częścią kraju obiecanego Izraelowi (zob. Wj 23,31; Lb 13,29; 34,6; Pwt 3,27; Joz 1,4). ${ }^{33}$ Chodzi zatem o aktualne miejsce ich zamieszkania. Drugie określenie (kerētîm), jak wspomnieliśmy wcześniej, pierwotnie oznaczało prawdopodobnie lud sąsiadujący z Filistynami. Z czasem jednak w ten sposób zaczęto określać samych Filistynów. Nazwa ta, jak się wydaje, wskazuje na miejsce pochodzenia tego ludu - Kretę. Stamtąd bowiem przybyła przynajmniej część „ludów morza”. ${ }^{34}$

Wreszcie orędzie zagłady skierowane zostało do Kanaanu ( $\left.k^{e} n a^{i} a n\right)$, który z formalnego punktu widzenia oznaczał terytorium Palestyny, Fenicji i Syrii w okresie przed osiedleniem się Izraelitów i przybyciem Filistynów na te ziemie. Jednak nazwa ta była odnoszona także do terenów południowych (zob. Joz 13,3) ${ }^{35}$ Uwzględniając zatem kontekst, należy uznać, że Kanaan w So 2,5 oznacza także kraj Filistynów, odwiecznych wrogów Izraela, zwłaszcza w okresie kształtowania się monarchii.

31 O.P. R o b e r t s o n, The Books of Nahum, Habakkuk and Zephaniah, s. 297.

32 D.W. B a k e r, Nahum, Habakkuk and Zephaniah: An Introduction and Commentary, Tyndale Old Testament Commentaries, t. 27, Downers Grove 1988, s. 103.

33 O.P. R o b e r t s o n, The Books of Nahum, Habakkuk and Zephaniah, s. 299.

34 S. P o t o c k i, Księga Sofoniasza, s. 173.

35 D.W. B a k e r, Nahum, Habakkuk and Zephaniah, s. 104. 
Właśnie przeciw krajowi Filistynów wypowiedziane zostało debar $J H W H$ - wypowiedziane w pierwszej osobie, w której przemawia Bóg za pośrednictwem proroka: „zniszczę cię [w'ha'ăbad'tîk], pozbawię mieszkańców". Czy jednak Juda wyciągnie naukę z postępowania Boga wobec ich zachodnich sąsiadów? Już wcześniej Bóg ostrzegał swój lud, że jeśli nie pozostanie Mu wierny, to może „być zniszczony" ('ābad) tak, jak ,zostały zniszczone” ('ābad) narody, które zamieszkiwały Kanaan przed nim (Pwt 8,19-20). Bóg znajduje upodobanie w ,zniszczeniu” ludu ('ābad) tak, jak znajdował upodobanie w czynieniu mu dobra (Pwt 28,63). Bóg złożył także uroczystą przysięgę, wzywając na świadków niebo i ziemię, że jego lud zostanie szybko „wyniszczony” ('ābad) w ziemi, którą idzie posiąść (Pwt 4,26; 30,18-19). Teraz ten proroczy dekret wchodzi w życie. Filistyni zostaną wyniszczeni w swojej ziemi, a dla mieszkańców Judy ma to być to ostrzeżenie przed nadchodzącą władzą, a nawet wręcz niezwykłym jej przeczuciem. ${ }^{36}$

Kraj Filistynów ponownie został nazwany „morskim wybrzeżem” (hebel hajjām) i właśnie wobec niego zostało wypowiedziane szczegółowe orędzie zniszczenia: „Morskie wybrzeże stanie się łąką dla pasterzy i zagrodami dla trzody" (w. 6). Jest to swoisty efekt wyniszczenia Filistei. Były to tereny dotychczas ludne i bogate z powodu handlu na krzyżujących się drogach biegnących między trzema kontynentami. Teraz staną się miejscem nieuprawianym przez człowieka, a odwiedzanym jedynie przez pasterzy wypasających swoje stada. Na owych łąkach jedynie z rzadka będą się znajdowały pomieszczenia dla pasterzy i ich trzód.

Pewną trudność stanowi tu zwrot: $n^{e} \hat{o} t k^{e} r \bar{o} t$ rō'îm. Pierwszy termin, $n^{e} \hat{o} t$ (1. mn. rodz. męskiego od nāwāh) oznacza „pastwiska” (2Sm 7,8; Iz 65,10; Ez 25,5). Natomiast rō'îm (1. mn. rodz. męskiego od $r \bar{a} ' \bar{a} h)$, to ,pasterze”, którzy byli zatrudniani przy wypasaniu trzody (Rdz 4,2; 13,7; Am 3,12; Jr 31,10). Niezrozumiałe i zbyteczne wydaje się w tym kontekście $k^{e} r o ̄ t$. Jedni widzą tu 1 . mn. od niespotykanego poza tym miejscem $k \bar{a} r \bar{h} h$, w znaczeniu „cysterna”,

36 O.P. R o be r t s o n, The Books of Nahum, Habakkuk and Zephaniah, s. 299. 
„legowisko". ${ }^{37}$ Inni wskazują na dittografię od nôt lub kar. ${ }^{38}$ LXX tłumaczy je terminem własnym Kreta, a Wulgata zupełnie pomija. Propozycja przedstawiona przez S. Potockiego wydaje się bardziej uzasadniona: „Prawdopodobnie jest to drugi raz napisane słowo $n^{e} \hat{o} t$ z błędną zamianą litery $n$ na $k " .{ }^{39}$

W kolejnym wersecie konsekwencje zagłady Filistynów zostały podane w odniesieniu do mieszkańców Judy, jednak nie wszystkich. „Wybrzeże przypadnie w udziale reszcie z domu Judy, na nim będą wypasać. W domach Aszkelonu będą spoczywali wieczorem, gdyż Pan, ich Bóg, ich nawiedzi i pozwoli im powrócić z niewoli” (w. 7).

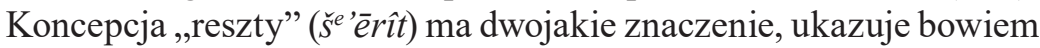
zarówno skutek sprawiedliwego sądu Bożego, jak i owoce Jego łaskawego błogosławieństwa. Sąd Boży przeciw grzechowi przyniesie tak drastyczny efekt, że narody zostaną do tego stopnia wyniszczone, iż jedynie reszta pozostanie ( $\mathrm{Rdz} 7,23$; Iz 17,6). Nawet takie okoliczności zawierają w sobie aspekt nadziei, ponieważ nie wszyscy ludzie ulegną zagładzie (por. Joz 10,40; Jr 50,26). Reszta, o której jest tu mowa (por. 1,4; 2,9; 3,13), uchodząc przed Bożym sądem, staje się symbolem nadziei Izraela, ponieważ obiecany sąd nie będzie miał charakteru totalnego. Motyw „,reszty” ( $\check{S}^{e}$ 'e $\left.r \hat{\imath} t\right)$ jest powszechnie znany u proroków (por. Jr 23,3; Am 5,15; Mi 2,12; 5,7-8), zarównow sensie ukazania surowego sądu Boga, jak i przedstawienia skutku działania Jego łaskawego miłosierdzia. Zniszczenie rzeczywiście przyjdzie, ale nie będzie to całkowite unicestwienie. ${ }^{40}$ Wcześniej Sofoniasz pisał na temat „przyjścia” Boga w kategoriach nadchodzącego sądu (1,8-9). Teraz mówi o „przyjściu” w odniesieniu do przyszłego zbawienia. Kiedy Pan podejmuje działanie na rzecz swojego ludu, to wówczas przywraca ludowi swoje błogosławieństwo.

37 Tamże, s. 300.

38 Hasło kerōt, tłum. P. D e c, w: L. K o e h 1 e r, W. B a u m g a r t n e r, J.J. S t a m m, Wielki stownik hebrajsko-polski i aramejsko-polski Starego Testamentu, t. I, Warszawa 2001, s. 472.

39 S. P o t o c k i, Księga Sofoniasza, s. 174.

40 D.W. B a k e r, Nahum, Habakkuk and Zephaniah, s. 104. 
Ostatnie zdanie wersetu można tłumaczyć na dwa sposoby: albo „powrócić z niewoli” (吕bîtām), albo „przywrócić bogactwa” (šsebutām). ${ }^{41}$ Koncepcja przywracania jest głęboko zakorzeniona w prawodawstwie deuteronomicznym. Prawodawca był przekonany, że po spełnieniu się wszystkich błogosławieństw i przekleństw, i jeśli lud rozważy to wszystko, wówczas Bóg pozwoli mu wrócić z niewoli, jeśli tylko powróci on do Boga, swojego Pana (Pwt 30,1-3). Tak jak wyrok skazujący przyjdzie po spełnieniu się przekleństw zawartych w Przymierzu, tak pozwolenie na powrót przyjdzie wraz ze spełnieniem warunków Przymierza. Zachodni sąsiedzi Judy zostaną zniszczeni bez jakiejkolwiek nadziei, jednak dla ludu Boga po zagładzie Filistynów pojawi się ocalenie. ${ }^{42}$

\section{Wyrocznia przeciw Moabitom i Ammonitom (So 2,8-11)}

Inaczej niż w poprzedniej sekcji, w wyroczni So 2,8-11, wymienione zostały jedynie dwie nacje: Moab i Ammon (ww. 8 i 9), choć za pewną wzmiankę etniczną można uznać zwrot „wszystkie wyspy narodów" (w. 11). W analizowanej perykopie pojawia się również kilka określeń Judy, choć nie wprost: „Mój lud” (w. 8), „reszta Mojego ludu”, „ci, którzy pozostali z Mojego narodu” (w. 9), „lud Pana Zastępów" (w. 10). Wyrocznia przeciw Moabitom i Ammonitom wyróżnia się z kontekstu również tym, że wyliczone zostały powody, dla których na narody spada kara: lżenie, poszerzanie swoich granic (w. 8), pycha, szydzenie i wywyższanie się (w. 10).

\section{Dane geograficzne}

W So 2,8 wymienione zostały dwa narody: Moab i synowie Ammona. W identycznym brzmieniu pojawią się one w 2,9.

${ }^{41}$ Zob. Ketib-Qere, w: K. E 11 ig e r, W. R u d olph (red.), Biblia Hebraica Stuttgartensia, Stuttgart 19975.

42 O.P. R o b e r t s o n, The Books of Nahum, Habakkuk and Zephaniah, s. 300. 
Moab (mô'āb) może oznaczać terytorium okupowanej przez Moabitów ziemi (tak Sdz 3,30; $2 \mathrm{Sm} 8,2 ; \mathrm{Jr} 48,4)$. Była to równina pierwotnie zamieszkana przez semickie plemię zwane Emitami (Pwt 2,10) albo Sutu, a potem przez Moabitów (Rdz 19,37; Lb 21,13; 22,7.8.10; 25,1 itd.). ${ }^{43}$ Terytorium Moabu rozciągało się na wschód od Morza Martwego. Na południu jego granicę wyznaczał potok Zared, a dalej graniczył on z Edomem. Na północy jego granicę wyznaczała rzeka i dolina Arnon, jednak nie była to trwała granica i często przesuwana była ponad Morze Martwe, a tam sąsiadami Moabu byli Izrael i Ammon. ${ }^{44} \mathrm{~W}$ naszym kontekście odnosi się jednak do mieszkańców tego rejonu (tak również w Lb 21,29; Jr 48,11.13). Pochodzenie tego narodu tradycja wiąże z synem Lota, zrodzonym z jego starszej córki. Moab był bratem Ammona, również syna Lota, zrodzonego jednak z jego młodszej córki ${ }^{45}$ Dlatego też Moabici i Ammonici są bardzo często wymieniani razem, ponieważ oba narody miały pochodzić z kazirodczego związku Lota, bratanka Abrahama, z córkami. Są oni także nazywani „synami Lota” (Pwt 2,9.19; Ps 83,9). Na początku swojej historii Moabici byli federacją nomadycznych plemion, które wędrowały ze stadami w poszukiwaniu pastwisk. Około XIII w. przed Chr. już byli osiedleni na terenach zdobytych na Emitach (Pwt 2,10-11), ${ }^{46}$ skoro według inskrypcji faraona Ramzesa II (ok. 1250 r. przed Chr.) armia egipska przeszła przez Moab i splądrowała niektóre jego miasta. W czasie wyjścia Izraelitów z Egiptu (ok. 1250 r.) Moabici byli więc już jednym z najbardziej znanych ludów w sąsiedztwie Kanaanu (Wj 15,15). Do pierwszych kontaktów Moabu z Izraelem doszło wówczas, gdy Mojżesz starał się zapewnić bezpieczne przejście swojemu ludowi przez równinę położoną na wschód od Morza Martwego, a więc przez teren Moabu. ${ }^{47}$

43 P.C. B o s a k, Leksykon wszystkich miejsc biblijnych, s. 614.

44 F.V. R e it e r e r, Moab, tłum. Ł. S i e m i e n i e c, w: F. K o g l e r, R. Eg g e r- W e n z e 1, M. E r n s, H. W i t c z y k (red.), Nowy Leksykon Biblijny, s. 494.

45 J.A. D e a r m a n, Moab, tłum. T. M i e s z k ow s k i, w: P.J. A c h t e m e i e r (red.), Encyklopedia Biblijna, s. 772.

46 P.C. B o s a k, Leksykon wszystkich miejsc biblijnych, s. 614.

47 J.A. D e a r m a n, Moab, s. 772. 
W dalszej historii Izrael często toczył wojny z Moabitami. W sąsiedztwie bowiem osiedliły się pokolenia Gada i Rubena (Lb 32,34-37), które później zostały wyparte przez Moabitów i Ammonitów. Z nimi walczył Saul (1Sm 14,47), a Dawid zmusił ich do uległości (2Sm 8,2). Po śmierci Salomona nadal nie było tu spokoju, a Mesza, król Moabu, w celu utrzymania panowania nad tą krainą, poświęcił swego pierworodnego syna (2Krl 3,4-27). ${ }^{48}$ Podboje ziem izraelskich za czasów panowania Meszy, które przypisywał on bogu Kemoszowi, opisuje tekst zawarty na steli Meszy, która została odkryta w 1868 r. w Dibonie, stolicy Moabu (por. Jr 48,46). ${ }^{49}$ Od VIII w. przed Chr. Moab musiał uznać zwierzchność najpierw Asyryjczyków, za panowania Tiglat-Pilesera III (728 r. przed Chr.), a następnie Babilończyków. Z Jr 27,3 wynika, że w czasie podbojów Nabuchodonozora królestwo to odgrywało jeszcze znaczącą rolę, jednak w okresie perskim Moab praktycznie już nie istniał, a jego tereny zajmowali przybysze z pustyni.

Synowie Ammona (bnê 'ammôn) byli północno-wschodnimi sąsiadami Mobitów, a zajmowane przez nich tereny rozciągały się na wschodnim brzegu Jordanu w górnym biegu potoku Jabbok. ${ }^{50}$ Według Rdz 19,30-38, Ben-Ammi był synem Lota i jego młodszej córki. On właśnie miał być praprzodkiem Ammonitów. Badania historyczne wskazują, że powstanie królestwa Ammonitów, na wschód od Jordanu, zbiegło się w czasie powstaniem kilku innych państw w obszarze syropalestyńskim w epoce późnego brązu i wczesnego żelaza (ok. 1500-1000 r. przed Chr.). Były to ludy Moabu, Edomu, Izraela i kilku innych państw aramejskich. ${ }^{51}$ Wprawdzie nie dysponujemy starożytnymi egipskimi dokumenami potwierdzającymi istnienie Ammona,

48 S. P o t o c k i, Księga Sofoniasza, s. 176.

49 S. S t a s i a k, Archeologia Palestyny, w: R. P i e t k i e w i c z (red.), Geografia $i$ archeologia biblijna $w$ zarysie, Wrocław 2011, s. 95-97.

50 F.V. R e i t e r e r, Ammon / Ammonici, tłum. M. S z c z e p a n i a k, w: F. K o g l e r, R. Eg g e r-We n z e 1, M. E r n s, H. W it c z y k (red.), Nowy Leksykon Biblijny, s. 21.

${ }_{51}$ J.A. D e a r m a n, Ammonici, tłum. M. Woj c i e c how s k i, w: P.J. A c ht e m e i e r (red.), Encyklopedia Biblijna, s. 26-27. 
tak jak to jest w przypadku Moabu, jednak współczesne badania archeologiczne dowodzą, że w XII w. przed Chr., współcześnie z Moabitami i Edomitami, Ammonici przybyli z terenów pustynnych do swych historycznych siedzib położonych na Zajordaniu, ze stolicą w Rabba. ${ }^{52}$ Wykopaliska potwierdzają także, że na obszarze obecnego Ammanu w okresie późnego brązu istniały stałe osiedla. Po wyjściu z Egiptu, w początkowym okresie wędrówki przez Kanaan, Izraelici odnosili się do Ammonitów przychylnie (Pwt 2,9), później jednak ze względu na różnice pochodzenia, odmienność języka, kultury, religii i obyczajów stali się oni jednym z głównych wrogów Izraela. Przyczyniło się do tego również i to, że w późnej fazie zasiedlania Kanaanu Izraelici zostali pokonani przez koalicję ammonicko-filistyńską. Działo się to w czasach Jeftego, a więc w okresie panowania sędziów. W późniejszym okresie walczył z nimi i pokonał ich Saul (1Sm 11). Pokonał ich także Dawid pod Rabba (1Sm 11,14-21). Nie mamy wiadomości, co w późniejszym okresie działo się z Ammonitami, jednak kiedy w okresie VIII i VII w. przed Chr. przygasło polityczne powodzenie Izraela i Judy, kultura ammonicka nadal się rozwijała, o czym świadczą inskrypcje i znaleziska archeologiczne. ${ }^{53}$ Ich głównym bóstwem był Milkom. Najazdy Ammonitów i umacnianie wpływów wśród Izraelitów wiązało się z propagowaniem kultu tegoż bóstwa (1Krn 20,2; Jr 49,1; So 1,5). Z tego więc powodu zrozumiałe i w pełni uzasadnione wydają się groźby, jakie prorocy kierowali przeciw temu ludowi (Jr 9,25; Ez 25,1-7; Am 1,13-15). ${ }^{54}$

W kontekście wyroczni na temat mieszkańców Moabu i Ammonu w So 2,9 pojawiają się imiona własne miast: Sodoma i Gomora.

Sodoma ( $s^{e} d \bar{o} m$ - „płomienie”), to jedno z miast Pentapolis, o których mowa jest w Rdz 14,2: Sodoma, Gomora, Adma, Seboim i Soar. Istniały one już w III i II tysiącleciu przed Chr. w dolinie Siddim, na południe od Morza Martwego, na granicy Kanaanu (Rdz 10,15-20), przypuszczalnie na obszarze dzisiejszych płytkich wód na

\footnotetext{
52 P.C. B o s a k, Leksykon wszystkich miejsc biblijnych, s. 50.

53 J.A. D e a r m a n, Ammonici, s. 27.

54 S. P o t o c k i, Księga Sofoniasza, s. 176.
} 
południowym krańcu tego morza. ${ }^{55}$ Choć dokładna lokalizacja Sodomy nie jest znana, to jednak przeprowadzone na początku XX w. po Chr. badania archeologiczne wskazują właśnie na taką lokalizację. Te same padania pozwalają na datowanie Sodoma na II tysiąclecie przed Chr. Datowanie to opiera się na porównywalnych wzorach osiedli występujących w tych okolicach oraz na założeniu, że taką datę zakłada chronologia opowiadań o patriarchach. Ostatnie badania powalają również przypuszczać, że już w III, a także na początku II tysiąclecia przed Chr. miasta na południowym i wschodnim wybrzeżu Morza Martwego były zamieszkane. Zarówno Sodoma, jak i Gomora były więc zamieszkane przez większość III tysiąclecia przed $\mathrm{Chr} .{ }^{56}$ Sodoma otrzymała symboliczny charakter z powodu całkowitego zniszczenia (Iz 1,9; Jr 49,18; Am 4,11; Rz 9,29) i z powodu grzesznego stylu życia jej mieszkańców (Iz 1,10-11; 3,9; Jr 23,14; Mt 11,23-24), którzy zachowywali się w sposób zwyrodniały, głównie w sferze seksualnej. Szerzył się przede wszystkim homoseksualizm (Rdz 19,4-11; 2P 2,7-8). Bóg zareagował na skargę na Sodomę i Gomorę i chciał zstąpić, aby zobaczyć nieprawość ich mieszkańców ( $\mathrm{Rdz} 18,21-22)$, jednak miasta były tak zdeprawowane, że w Sodomie nie znalazło się nawet dziesięciu sprawiedliwych, dlatego jej ocalenie okazało się niemożliwe (Rdz 18,23-33). Lot, jedyny sprawiedliwy (Mdr 10,6), przed zniszczeniem miasta został zabrany przez wysłanników Boga (Rdz 19,15-17). Miasto zaś leżące wcześniej na żyznych terenach $(\mathrm{Rdz} 13,10)$ zostało całkowicie zniszczone deszczem siarki i ognia (Rdz 19,24-29). ${ }^{57}$ Kara, jaka spadła na Sodomę, była widziana jako skutek zapalczywości Boga i Jego gniewu (Pwt 29,22). Nic więc dziwnego, że Sodoma stała się swoistym symbolem wymierzonej przez Boga kary za występki człowieka przeciw naturze.

55 P.C. B o s a k, Leksykon wszystkich miejsc biblijnych, s. 775.

56 J.A. D e a r m a n, Sodoma, tłum. E. S z y mula, w: P.J. A c h te m e i e r (red.), Encyklopedia Biblijna, s. 1129.

${ }_{57}$ F.V. R e i t e r e r, Sodoma, thum. T. S i e m i e n i e c, w: F. K o g l e r, R. E g g e r - W e n z e 1, M. E r n s, H. W i t c z y k (red.), Nowy Leksykon Biblijny, s. 689. 
Gomora ("ămōrāh - „pokryty wodą”), to miasto, podobnie jak Sodoma, należące do Pentapolis, a więc położone w południowym Kanaanie, na południowy zachód od Morza Martwego i zamieszkane przez potomków Chama ( $\mathrm{Rdz} 10,19-20)$. Gomora stanowiła południową granicę Kanaanu. Były to ziemie pierwotnie bardzo urodzajne (Rdz 13,10; Pwt 32,32). Miasto zostało splądrowane przez królów północy, Amrafela, Arioka, Kedorlaomera i Tidala (Rdz 14,1-25). ${ }^{58}$ Według przekazu Starego Testamentu Gomora, wymieniania zawsze razem z Sodomą, została zniszczona przez Boga z powodu nieprawości jej mieszkańców (por. Rdz 19,2-9). Z teologicznego punktu widzenia kara ta jest w miarę prosta do wyjaśnienia. Nieprawość mieszkańców Gomory została ukarana, a ona sama stała się symbolem niegodziwości i zła moralnego (Iz 1,10; 3,9), a także ostrzeżeniem przed nadchodzącym sądem (Iz 1,9; So 2,9; Łk 17,29; 2P 2,6; Jud 7). Z punktu widzenia obserwowanej przez współczesnych patriarchom ludzi nieurodzajnej ziemi, która rozciągała się na południowy zachód od Morza Martwego, próbowano odpowiedzieć na pytanie: Czy zawsze na tych terenach znajdowano jedynie smołę, siarkę i sól? Nie zawsze tak było, jak się dowiadujemy ze Starego Testamentu: „Wtedy Lot rozejrzał się i zobaczył, że cała kraina nad Jordanem była tak samo dobrze nawodniona jak ogród Pana, jak ziemia egipska aż do Soaru, zanim Pan zniszczył Sodomę i Gomorę" $(\mathrm{Rdz} 13,10) .{ }^{59}$ Gomora zatem byłaby zniszczona w jakimś kataklizmie (Rdz 18,17-19,29), niewykluczone, że naturalnym, uważanym za karę Boga za popełnianie ciężkich grzechów.

W końcowej części wyroczni przeciw Moabitom i Ammonitom (So 2,8-11) spotykamy jeszcze jedno określenie: „wszystkie wyspy narodów" (kōl 'ijjê haggôjim; w. 11). Hebrajski termin 'î LXX tłumaczy przez hē nēsos, a więc „wyspa”, jednak możliwe jest również

58 P.C. B o s a k, Leksykon wszystkich miejsc biblijnych, 372.

59 F. Gra d 1, Gomora, tłum. T. S i e m i e n i e c, w: F. K o g l e r, R. Eg ge r- W e n z e 1, M. E r n s, H. W i t c z y k (red.), Nowy Leksykon Biblijny, s. 230. 
znaczenie „półwysep”, „wybrzeże”. ${ }^{60}$ Biorąc pod uwagę, że ludy zamieszkujące owe wyspy i wybrzeża nazwane zostały haggôjim, należy uznać, że określenie kōl 'ijjê haggôjim odnosi się albo do wszystkich narodów (Rdz 10,5.20; 17,4; Wj 34,10; Lb 24,20; 1Sm 8,5), albo tylko do narodów wrogich Izraelowi, oddanych bałwochwalstwu (Wj 34,34; Kpł 18,24; 25,44; 26,33; Lb 14,15; Pwt 4,27). ${ }^{61}$ Biorąc pod uwagę, że w bezpośrednim kontekście poprzedzającym Sofoniasz pisał na temat zwycięstwa JHWH nad bóstwami pogańskimi (w. 11a), należałoby przychylić się do tej drugiej opinii, według której przedstawiciele nawet najodleglejszych zakątków ziemi oddadzą cześć JHWH.

Treść i znaczenie wyroczni przeciw Moabitom i Ammonitom

Sofoniasz zapowiada przyszłą klęskę Moabitów i Ammonitów (ww. 9 i 11a) wraz z jej uzasadnieniem (ww. 8 i 10), czego nie zrobił w wyroczni przeciw Filistynom $(2,4-7)$. Na końcu dodał jeszcze eschatologiczną zapowiedź powszechnego kultu JHWH (w. 11b). Dlatego też właśnie w takim porządku omówimy wyrocznię.

\section{Uzasadnienie klęski Moabitów i Ammonitów}

Słowne urąganie (herepāh) lub obelgi Moabu (3,18; por. Iz 25,8; 51,7; Ez 16,57; 36,15) i zniewagi (gidûfîm) lub bluźnierstwa synów Ammona (por. Lb 15,30; 2Krl 19,6.22; Iz 51,7; Ez 5,15) skierowane są przeciw Izraelowi, ludowi Przymierza (w. 8). ${ }^{62}$ Pierwszy z terminów (herepāh) oznacza „urąganie”, „drwina”, „hańba”, „wstyd”. ${ }^{63}$ Działania

${ }^{60}$ Hasło 'î, tłum. K. M a d a j, M. B a r a now s k i, w: L. K o e h 1 e r, W. B a u mg a r $\mathrm{t} \mathrm{n}$ e r, J.J. S t a m m, Wielki słownik hebrajsko-polski i aramejsko-polski Starego Testamentu, t. I, s. 38 .

${ }^{61}$ S. P o t o c k i, Księga Sofoniasza, s. 179.

62 D.W. B a ke r, Nahum, Habakkuk and Zephaniah, s. 105.

${ }_{63}$ Hasło '̂, tłum. J. K r ę c i d ło, w: L. K o e h 1 e r, W. B a u m g a r t n e r, J.J. S t a m m, Wielki stownik hebrajsko-polski i aramejsko-polski Starego Testamentu, t. I, s. 338. 
te mogą mieć charakter zarówno słowny, jak i czynny (zob. 1Sm 11,2; Iz 51,7; Ez 5,15; 16,57; 21,33; Mi 6,16) ${ }^{64}$ Drugi z terminów (gidûfîm) jest znacznie rzadszy (występuje jeszcze tylko w Iz 43,28; 51,7; Ez 5,15) i oznacza „zniesławienie”, „zniewagę". ${ }^{65}$ Wina Moabitów i Ammonitów została podsumowania w słowach: 'ăšer hêreph 'et-'ammî. Jest to w zasadzie powtórzenie pierwszego członu zdania, jedynie ze zmianą rzeczownika here $p \bar{a} h$ na czasownik $h r f \mathrm{w}$ koniugacji Piel, który ma podobne znaczenie. Ostatni człon zdania wyraża kolejną winę narodów wbijających się w pychę: wajjagedîlû 'al gewâlām. Także to działanie można potraktować jako zniewagę słowną, choć znaczenie tych słów nie jest pewne. Dosłownie tłumaczenie brzmi następująco: „i wywyższali się na ich granicy”. Zdanie to jednak dopuszcza dwojakie rozumienie wypowiedzi. Z jednej strony mogło chodzić o ekspansję terytorialną Moabitów i Ammonitów: „i zajmowali ich [Izraela] granice" (Przekład Ekumeniczny). ${ }^{66} \mathrm{Z}$ drugiej strony mogło chodzić o wynoszenie się ponad Izraelitów „i rozpierają się w swoich granicach" (Biblia Tysiąclecia). Rdzeń gdl w koniugacji Hifil, z następującym po nim przyimkiem 'al, oznacza często wypływające z pychy działanie (por. Jr 48,26; Ez 35,13). Możemy więc przyjąć, że wina Moabitów i Ammonitów wobec Izraela polegała przede wszystkim na słownych zniewagach i wywyższaniu się.

Na pychę Moabitów i Ammonitów wskazują również słowa: „To spotka ich za pychę, ponieważ szydzili i wywyższali się nad lud Pana Zastępów” (w. 10). Zmienia się sposób wypowiedzi. Od wypowiedzi Boga w pierwszej osobie (ww. 8-9), do mówienia przez proroka o Bogu w trzeciej osobie. W wersecie podkreślone zostało złamanie pychy, która przez wiele stuleci charakteryzowała Moabitów i Ammonitów (zob. Iz 16,6; Jr 48,29). Już przed Sofoniaszem Izajasz zapowiadał, że w ciągu trzech lat od wypowiedzianej przez niego wyroczni

${ }^{64}$ S. P o t o c k i, Księga Sofoniasza, s. 176.

${ }_{65}$ Hasło gidûf/ gidûfāh, tłum. J. K u c ha r s k i, w: L. K o e h l e r, W. B a u m$\mathrm{g}$ a r $\mathrm{t} \mathrm{n}$ e r, J.J. S t a m m, Wielki słownik hebrajsko-polski i aramejsko-polski Starego Testamentu, t. I, s. 169.

66 D.W. B a k e r, Nahum, Habakkuk and Zephaniah, s. 105. 
Moab zostanie upokorzony z powodu swojej arogancji (Iz 16,13-14). Widocznie jednak kara ta nie była wystarczająca do złamania narodowej pychy wobec ludu Boga, który stał się przedmiotem kpin, jak gdyby został złapany wśród złodziei, skoro Moabici potrząsali nad nimi głowami, ilekroć o nim mówili (Jr 48,27). ${ }^{67}$ Cała wina Moabitów i Ammonitów polega na „pysze” ( $g \bar{a} ’ \hat{o} n)$, ,szydzeniu” (hêerepû) $\mathrm{i}$,wywyższaniu się" (jjagedilû) nad Izraela. W pierwszym pojęciu mieści się idea wielkości i wzniosłości, które to cechy przysługują wyłącznie Bogu (Wj 15,7; Iz 2,10; 24,13; Mi 5,3). Drugie wskazuje na poczucie własnej wielkości, czyli pychy (Kpł 26,19; Iz 13,11; 14,11; 16,6 ; Jr 13,9) ${ }^{68}$ Trzecie pojęcie nawiązuje do pysznej postawy Moabitów i Ammonitów wobec Izraela, o której pisał Sofoniasz w 2,8. Jak zauważyliśmy już wcześniej, $g d l$ w koniugacji Hifil połączone z następującym 'al często wskazuje na wypływające z pychy działanie wobec kogoś.

\section{Zapowiedź klęski Moabitów i Ammonitów}

Jej opis został przedstawiony przez Sofoniasza dwustopniowo (ww. 9 i 1la), podobnie jak jej uzasadnienie. Ogłoszenie wyroku zostało poprzedzone uroczystym haj 'ānî (w. 9), które ma swoje odpowiedniki/warianty w innych tekstach Starego Testamentu: haj $J H W H(\mathrm{Sdz} 8,19 ; 1 \mathrm{Sm} 14,39)$, haj ha'élōhîm (2Sm 2,27), czy też haj 'él (Hi 27,2) ${ }^{69}$ Jeśli słowa te zostają włożone w usta JHWH, to ma szczególnie złowieszcze znaczenie dla adresatów wyroczni. Spośród około dwudziestu razy, w których pojawiają się one w Starym Testamencie, zawsze wprowadzają orędzie kary, z dwoma możliwymi wyjątkami (Iz 49,18, Ez 33,11). W naszym kontekście ma ono następująca wymowę: jeśli Bóg naprawdę istnieje, to zniszczenie Moabu i Ammonu jest pewne. Skoro istnienie jest domeną Boga, to On jest również

${ }^{67}$ O.P. R o b e r t s o n, The Books of Nahum, Habakkuk and Zephaniah, s. 306.

${ }^{68}$ S. P o t o c k i, Księga Sofoniasza, s. 178.

69 Tamże, s. 177. 
źródłem wszelkiego życia. Nic bez Niego nie istnieje. ${ }^{70}$ Zaimek osobowy 'ānî zyskuje swoje uszczegółowienie w kolejnym uroczystym sformułowaniu: $n^{e}$ 'um JHWH cebā' ôt 'èlōhê Jiśerā'êl. Tytuł JHWH $c^{e} b \bar{a}$ 'ot począwszy od Pierwszej Księgi Samuela jest używany do określenia Boga Izraela ('êlōhê Jiśerāêl). Pierwszy podkreśla Jego naturę, jako wojownika, który walczy na rzecz swojego ludu (por. Ha 3,8-15), a drugi wskazuje na fakt, że jest On również Bogiem swojego ludu i pozostaje z nim w bardzo ścisłej relacji. ${ }^{71}$ Zwłaszcza ten ostatni tytuł podkreśla szczególne władzę Boga nad Izraelem. Imię 'Ělōhîm odnosi się on bowiem do Boga, Stwórcy i Opiekuna świata (por. Rdz 1,1-2,3; Pwt 4,32; Iz 13,19; Jr 50,40), a imię narodu lub osoby wymieniona w następstwie, wskazuje na tych, z którymi Bóg wszedł w przymierze, nawiązując $\mathrm{z}$ nimi szczególne relacje.$^{72}$

Porównanie Moabu i Ammonu do Sodomy i Gomory nie jest zaskakujące ze względu na ich pochodzenie: oba narody uważane były za potomków pochodzących z kazirodczych związków córek Lota z pijanym ojcem, co wydarzyło się po ucieczce ze zniszczonej Sodomy i Gomory (Rdz 19,30-38). ${ }^{73}$ Unicestwienie Sodomy i Gomory jest uważane za symboliczne zniszczenie sprowadzone przez Boga w celu pomszczenia grzechu (por. Pwt 29,23-24). Historia tego wydarzenia musiała być żywa wśród Moabitów i Ammonitów, którzy zamieszkiwali wybrzeże Morza Martwego i często mieli okazję oglądać skutek Bożego gniewu, jaki dotknął Sodomę i Gomorę. Kolejne pokolenia ludzi zamieszkujących na tych terenach miały okazję obserwowania skutków tej niezwykłej katastrofy. A teraz przyszły los obu narodów, obwarowany przysięgą Boga, ma być identyczny jak obu miast. Całe ich terytorium stanie się podobne do Sodomy i Gomory, które zostały scharakteryzowane w tradycji deuteronomistycznej: „Cała jego ziemia jest siarką, solą i pogorzeli-

70 O.P. R o b e r t s o n, The Books of Nahum, Habakkuk and Zephaniah, 304.

71 D.W. B a k e r, Nahum, Habakkuk and Zephaniah, s. 105-106.

72 S. P o t o c k i, Księga Sofoniasza, s. 177.

73 L. W a 1 k e r, Zephaniah, s. 554; D.W. B a k e r, Nahum, Habakkuk and Zephaniah, s. 106. 
skiem! Nie będzie obsiewana, nic na niej nie wyrośnie i nie wzejdzie żadna trwa" (Pwt 29,22). ${ }^{74}$

Zagłada została opisana za pomocą trzech dwuwyrazowych określeń. Pierwsze to mimešaq ḩārûl, nie występuje ono nigdzie indziej w Starym Testamencie, jednak słowniki optują za znaczeniem ,czerwona, zniszczona ziemia". ${ }^{75}$ Takie znaczenie potwierdza również pojęcie hậrûl, które oznacza „chwast”, „dzika roślinność” czy też „krzewy rosnące na nieużytkach” (por. Prz 24,31; Hi 30,7). ${ }^{76}$ Drugie określenie to mike rēh-melah. Także mikerēh występuje jedynie u Sofoniasza, jednak pojęcie to wyraźnie nawiązuje do źródłosłowu rdzenia krh, czyli „drążyć”, „ryć”, w znaczeniu terenu, na którym wydobywa się sól (hebr. melah). ${ }^{77}$ Trzecie określenie to še māmāh 'ad-'ólām, którego pierwszy człon oznacza „pustkowie”, „spustoszenie” (por. So 1,$13 ; 2,4) .{ }^{78}$ Chodzi zatem o pustkowie, którego nikt przez długi czas ('ad-'ōlām) nie będzie uprawiał. Na koniec należy podkreślić, że wszystkie trzy elementy dotyczące kary pochodzą z opowiadania o zagłady Sodomy i Gomory: rośliny (Rdz 19,25; Pwt 29,23), sól (Rdz 19,26; Pwt 29,23) i długi czas spustoszenia (Iz 13,19-20; Jr 50,39-40). ${ }^{79}$

Beneficjentami kary, która spadnie na Moab i Ammon, będą ci, którymi oni pogardzali (zob. w. 8), a zostali przez proroka określeni dwoma pojęciami. Pierwsze, to še 'êrît, znane z 2,7, które z formalnego punktu widzenia oznacza tych, którzy pozostali po klęsce, pogromie, a w naszym kontekście chodzi o pozostałych przy życiu Izraelitów. $\mathrm{W}$ pismach prorockich pojęcie to zostało pogłębione i przystosowane

74 O.P. R o b e r t s o n, The Books of Nahum, Habakkuk and Zephaniah, s. 305.

75 Hasło mimešaq, tłum. M. K a n t o r, w: L. K o e h 1 e r, W. B a u m g a r t n e r, J.J. S t a m m, Wielki stownik hebrajsko-polski i aramejsko-polski Starego Testamentu, t. I, s. 561.

76 Hasło ḥārûl, tłum. J. K r ę c i d ło, w: tamże, s. 333.

77 S. P o t o c k i, Księga Sofoniasza, s. 178.

78 Hasło šemāmāh, tłum. P. D e c, w: L. K o e h le r, W. B a u m g a r t n e r, J.J. S t a m m, Wielki słownik hebrajsko-polski i aramejsko-polski Starego Testamentu, t. II, s. 535.

79 D.W. B a k e r, Nahum, Habakkuk and Zephaniah, s. 106. 
do wyrażenia idei czasów eschatologicznych, na określenie tych, którzy uczestniczyć będą nowej społeczności mesjańskiej (por. 2Sm 14,7; 2Krl 21,14; 2Krn 36,20; Iz 37,32; 46,3; Jr 6,9; 23,3; Ez 9,8). ${ }^{80}$ Właśnie owa reszta „w odwecie zagarnie łupy” (jebāzzûm) Mobitów i Ammonitów. Drugie określenie Izraela, to jeter gôjî, które oznacza „to, co zostało pozostawione, reszta”. ${ }^{81}$ Chodziłoby zatem o tych z narodu wybranego, którzy zostali zachowani, pozostawieni przy życiu (por. Pwt 3,11; 28,54; Joz 12,4; 2Sm 21,2; Jr 29,1; Mi 5,2). Oni właśnie ,zajmą dobra” (jineḥālûm) dwóch narodów, które nad nich się wywyższały (por. Wj 23,30; Lb 35,8; Pwt 19,14). ${ }^{82}$ Zamiast być przedmiotem inwazji obcych narodów, Izraelici sami będą łupili swoich odwiecznych wrogów (por. Iz 11,14; 24,3; Am 3,11), zajmując ich ziemie, tak jak czynili to w czasie zajmowania Kanaanu (por. Rdz 15,7; 22,17; Pwt 1,8). ${ }^{83}$

Druga część opisu klęski Moanitów i Ammonitów została przedstawiona w So 2,1la. Ta część wyroczni z jednej strony stanowi swoiste podsumowanie myśli o karze dla Moabitów i Ammonitów, ${ }^{84}$ $z$ drugiej jednak strony, prorok wraca do geograficznej i historycznej narracji na temat tych narodów, aby przejść do całej reszty świata. ${ }^{85}$ W rzeczywistości dotknięty zostaje podstawowy problem, bo właśnie religia leżała u podstaw wyniosłości Moabu i Ammonu. Stwierdzenie, że JHWH „okaże się straszny [nôrā'] dla nich”, sugeruje możliwość teofanii, bowiem natura Boga polega na Jego absolutnej wyjątkowości. Jego wielkość tak absolutnie przekracza ludzką wyobraźnię, że przejaw Jego prawdziwej natury może jedynie wzbudzać strach i lęk. Bóg, zapewniając Izraela, że chce mu dać w posiadanie inne narody, zachęcał go, by nie bał się innych narodów, ponieważ jego Bóg jest

80 S. P o t o c k i, Księga Sofoniasza, s. 175.

${ }_{81}$ Hasło jeter, tłum. J. S e r e m a k, w: L. K o e h 1 e r, W. B a u m g a r t n e r, J.J. S t a m m, Wielki slownik hebrajsko-polski i aramejsko-polski Starego Testamentu, t. I, s. 427.

82 S. P o t o c k i, Księga Sofoniasza, s. 179.

83 D.W. B a ke r, Nahum, Habakkuk and Zephaniah, s. 106.

84 Tak S. P o t o c k i, Księga Sofoniasza, s. 178.

85 Tak D.W. B a k e r, Nahum, Habakkuk and Zephaniah, s. 106-107. 
„Bogiem wielkim i straszliwym” ('êl gādôl wenôrā'), który usunie je sprzed oblicza swojego ludu (Pwt 7,21). Izrael ma się lękać jedynie Jego, bo On jest władcą nieba i ziemi, Bogiem ponad innymi bogami i Panem panujących, Bogiem ,wielkim i straszliwym” (haggibbōr wehannôrā; Pwt 10,17). Teraz, kiedy Bóg powraca do realizowania swojego zobowiązania wobec Izraela, co do poddania mu wszystkich ludów, ukazuje absolutnie niezwykły element swojej natury. ${ }^{86}$ Podbój sąsiednich krajów dopełniony zostanie przez objawienie się Pana i Jego straszliwej natury wśród nich. Owa straszliwa moc JHWH (por. Wj 34,10; Ps 47,2; 66,5; 89,7) objawi się, gdy „wniwecz obróci” (rāzāh „wszystkie bóstwa ziemi” (kôl 'élōhê hā'ārec). ${ }^{87}$ Moabici i Ammonici, niezdolni do utrzymania swoich terytoriów, dawniej bogaci i syci, teraz będą przymierać głodem. Ziemia nie przyniesie plonów, które mogliby ofiarować swoim bogom, a ci znikną z powodu braku zainteresowania ze strony dotychczasowych swoich wyznawców. ${ }^{88}$

\section{Eschatologiczna zapowiedź powszechnego kultu JHWH}

Nie tylko moc bogów zostanie obrócona wniwecz, lecz także ci, którzy dotychczas ich czcili, teraz oddadzą pokłon JHWH. Jak już zostało wspomniane wyżej, wyrażenie kōl 'ijjê haggôjim należy rozumieć jako „najodleglejsze zakątki ziemi”. Skoro w bezpośrednio poprzedzającym kontekście mowa była o zwycięstwie JHWH nad bóstwami pogańskimi, to w naszym kontekście wypowiedź tę należy rozumieć w takim sensie, że przedstawiciele najodleglejszych zakątków ziemi oddadzą cześć JHWH ${ }^{89}$ „we własnym kraju” ('îs mimeqômô). W dotychczasowych tekstach prorockich dominowało przekonanie, że cudzoziemcy będą pielgrzymowali do Jerozolimy

${ }^{86}$ O.P. R o b e r t s o n, The Books of Nahum, Habakkuk and Zephaniah, s. 307.

87 D.W. B a k e r, Nahum, Habakkuk and Zephaniah, s. 107.

88 O.P. R o b e r $\mathrm{t}$ s o n, The Books of Nahum, Habakkuk and Zephaniah, s. 308. Zob. też wypowiedź L. Walkera: „The Lord destroys the gods by destroying the nations that depend on these gods; these deities have no real existence apart from the people who serve them (1Cor 8:4-6)"; L. Wa 1 k e r, Zephaniah, s. 554.

${ }^{89}$ S. P o t o c k i, Księga Sofoniasza, s. 179. 
(por. Iz 2,3; 66,23; Mi 4,1), aby tam sprawować powszechny kult JHWH. Teraz Sofoniasz wyraża przekonanie, że kult Jedynego Boga nie będzie już ograniczony do jednego miejsca i jednego narodu, lecz wszyscy poznają JHWH (zob. 3,9) i będą Go czcili w swoich krajach. Sofoniasz jednak nie był pierwszym, który sugerował tak radykalną zmianę co do uwielbienia Boga przez obce narody. Izajasz nie tylko zapowiadał napływ narodów do Jerozolimy, lecz także pisał: „W tym dniu stanie ołtarz Pana pośrodku ziemi egipskiej, a stela Pana przy jej granicy” (Iz 19,19); „Pan da się poznać Egiptowi, Egipcjanie poznają Pana w tym dniu i będą Go czcić ofiarami krwawymi i ofiarami pokarmowymi, będą składać śluby Panu i je wypełniać” (Iz 19,21). Asyryjczycy będą przechodzili przez Izrael, aby w Egipcie czcić JHWH, a Egipcjanie będą zdążali do Asyrii, aby tam Mu służyć (zob. Iz 19,23). Sofoniasz nie był również ostatnim, który w ten sposób ukazał perspektywę ,tego dnia”. Malachiasz pisał na temat kadzidła i czystych ofiar, które będą składane Panu na każdym miejscu, od wschodu aż do zachodu słońca (M1 1,11) ${ }^{90}$

Wyrażenie kōl 'ijjê haggôjim jest paralelne do kôl 'élōhê hà'ārec. Zatem zniweczeniu ,wszystkich bóstw ziemi” odpowiada powszechny kult prawdziwego Boga. ${ }^{91}$

\section{Wyrocznia przeciw Kuszytom (So 2,12)}

Niezwykle zwięzła wyrocznia składa się właściwie z jednego zdania, którym wymieniona została nazwa narodu oraz kara, która ma na niego spać, bez podania uzasadnienia.

\section{Dane geograficzne}

Kuszyci (kûšîm - „czarny”) - Kusz, Etiopią albo Nubią nazywane były wszystkie kraje położone na południe od Egiptu, zwłaszcza kraje położone wzdłuż Nilu, na południe od drugiej katarakty, na południe

90 O.P. R o b e r t s o n, The Books of Nahum, Habakkuk and Zephaniah, s. 308.

91 D.W. B a k e r, Nahum, Habakkuk and Zephaniah, s. 107. 
od Asuanu. ${ }^{92}$ P.J. Achtemeier przy haśle „Kusz”, wprost odsyła do hasła „Etiopia” i stwierdza: „U szczytu potęgi Etiopii nazwa ta jednak oznaczała obszar sięgający aż do zbiegu Nilu Błękitnego i Białego w Chartumie, dzisiejszy północny Sudan (nie należy więc mylić Etiopii starożytnej z obecną, czyli Abisynią)". ${ }^{93} \mathrm{~W}$ kraju położonym na południe od Egiptu (Ez 29,10; 30,4) żyją ludzie o czarnym kolorze skóry (Jr 13,23). Kraj ten uchodził za koniec ówczesnego świata (por. Am 9,7), a w czasach ostatecznych, nawet Kuszyci wymienieni są wśród czcicieli JHWH (So 3,10).$^{94}$ Jak trafnie jednak zauważa S. Potocki, w Biblii istnieje wprawdzie hebrajski termin oznaczający Egipt (mic rajim), a Kûš określa tam Etiopię, to jednak z historii wiadomo, że władcy Egiptu z dynastii XXV wywodzili się właśnie z Nubii (Etiopii), co więcej, faraon Tirhakah, zwany był w Starym Testamencie królem Kusz (2Krl 19,9; Iz 37,9), choć faktycznie rządził całym Egiptem. Sofoniasz żyje i działa w czasach jego następcy, Psammetycha (663-609 przed Chr.). Należy zatem przypuszczać, że nazwę „Kuszyci”, oznaczającą narodowość poprzednich faraonów, prorok rozszerzył na wszystkich mieszkańców wielkiego państwa egipskiego. ${ }^{95}$

Relacje Izraela z Egiptem sięgają czasów patriarchów (zob. np. Rdz 12,9-20; 39,1-47,26), lecz od czasu wyjścia nie mogło być mowy o żadnych relacjach przyjacielskich między tymi dwoma krajami. W późniejszym jednak czasie dochodziło do chwilowego ocieplenia relacji: Salomon kupił w Egipcie wozy i konie (zob. 1Krl 10,28-29), Jeroboam szukał tam schronienia (zob. 1Krl 11,40), tam wysyła swoich posłów Ozeasz (zob. 2Krl 17,4). Jednak znane były również wzajemne walki (zob. np. 1Krl 14,25-26; 2 Krn 12,2-10; 35,20-21). Wiemy, że król Jozjasz, z którego panowaniem była związana działalność Sofoniasza

92 P.C. B o s a k, Leksykon wszystkich miejsc biblijnych, s. 550.

93 D. B a ly, Etiopia, tłum. M. W oj c i e c how ski, w: P.J. A c h te meie r (red.), Encyklopedia Biblijna, s. 267.

94 F.V. R e i t e r e r, Kusz, thum. T. S i e m i e n i e c, w: F. K o g l e r, R. Eg g e r-We n z e 1, M. E r n s, H. W i t c z y k (red.), Nowy Leksykon Biblijny, s. 419-420.

${ }^{5}$ S. P o to c k i, Księga Sofoniasza, s. 179; L. W a 1 ke r, Zephaniah, s. 555, D.W. B a k e r, Nahum, Habakkuk and Zephaniah, s. 107. 
(zob. So 1,1) ${ }^{96}$ zginął pod Megiddo, pokonany przez faraona Neko (2Krl 23,29). Niewykluczone, że doszło do tego z powodu koalicji antyasyryjskiej, w którą wszedł Jozjasza, a Neko II spieszył ze wsparciem dla Asyrii, zagrożonej ze strony Babilonii. ${ }^{97}$

\section{Treść i znaczenie wyroczni przeciw Egiptowi}

Biorąc pod uwagę wyżej wspomnianą możliwą koalicję między Egiptem a Asyrią w czasach Sofoniasza, niektórzy uczeni są zdania, że obie wyrocznie należałoby rozpatrywać razem, podobnie jak w Rdz 10,8.$^{98}$ Wydaje się jednak uzasadnione rozpatrywanie obu wyroczni oddzielnie, bowiem zapowiedź kary, nawet jeśli nie jednakowa pod względem długości zapowiedzi, to jednak jest różnorodna - Egipcjanie będą przebici mieczem (w. 12), a Asyria stanie się pustkowiem (ww. 13-14). Sofoniasz jednak nie podaje uzasadnienia kary, jaka ma spaść na Egipt.

Jest to niezwykle zwięzła, wręcz fragmentaryczna wyrocznia. Nasuwają się pytania: Dlaczego prorok podał tak mało szczegółów odnośnie do zniszczenia Egiptu? Dlaczego nie rozwinął tematu spustoszenia ziemi, które to dane znajdujemy w kolejnej wyroczni? Gwałtowana zmiana osoby z trzeciej w 2,10-11 na pierwszą w 2,12, mogła być celowym zabiegiem literackim. Szybki cios mieczem został zadany natychmiast po wymienieniu przez JHWH imienia „Kuszyci”. Tego rodzaju słownictwo podkreśla również bezpośrednie zaangażowanie Boga w wykonanie wyroku. Kuszyci zostaną zabici ręką Boga i Jego osobistym mieczem. ${ }^{99}$

96 Sofoniasz przyczynił się swoim przepowiadaniem do tego, by dokonała się reforma osiemnastoletniego króla Jozjasza w 622 r. przed Chr., gdy Asyria chyliła się ku upadkowi; S. G ą d e c k i, Wstęp do ksiag prorockich Starego Testamentu, Gniezno 1993, s. 133.

97 S. P o to c k i, Księga Sofoniasza, s. 180.

98 J.H. W a $1 \mathrm{t}$ o n, V.H. M a $\mathrm{t}$ h h e w s, M.W. C h a v a $\mathrm{l}$ a s, Komentarz historyczno-kulturowy do Biblii Hebrajskiej, tłum. Z. K o ś c i u k, Warszawa 2005, s. 915.

99 O.P. R o b e r t s o n, The Books of Nahum, Habakkuk and Zephaniah, s. 309. 
Głównym więc motywem wyroczni przeciw Egiptowi jest „miecz” (hereb). W Starym Testamencie był on często obrazem kary w postaci wojny zesłanej przez Boga (zob. np. Wj 22,23; Kpł 26,6; Iz 1,20; Jr 4,10; 25,29). ${ }^{100}$ Związany przysięgą Bóg użył miecza, aby wytępić wszystkich niegodziwych ziemi. Ten sam miecz Pański zobaczył w dłoni posłańca Pańskiego Jozue, kiedy rozważał atak na Jerycho (Joz 5,13). Ten sam motyw jest wiodący w opisie bitwy Gedeona przeciw Madianitom (Sdz 7,20). ${ }^{101}$ Ezechiel nazywa Nabuchodonozora mieczem, który Bóg da w jego rękę, a on wyciągnie go przeciw ziemi egipskiej (Ez 30,24-25). ${ }^{102}$ Wydaje się jednak, że wyrocznia So 2,12 odzwierciedla raczej wydarzenia z czasów Ezechiasza (728-699 przed Chr.), Izajasza i oblężenia Jerozolimy przez Sennacheryba (704-681 przed Chr.), o czym mowa jest w 2Krl 19,1-37. Sofoniasz jednak zapowiada wydarzenia, które miały nadejść za panowania Jozjasza (641-609 przed Chr.) faraona Psametycha I (664-610 przed Chr.) i władcy asyryjskiego, Asurbanipala (669-631 przed Chr.), który złupił Teby, religijną stolicę Egiptu. Wiedzę na tematy tych wydarzeń wydaje się mieć także Nahum, który pisząc na temat zagłady Niniwy, zauważa: „Czy jesteś lepsza niż No-Amon, ${ }^{103}$ które leżało między rzekami? Wody niczym mur je otaczały i morze było jego wałem. Jego siłą był Kusz i Egipt..." (Na 3,8-9a). ${ }^{104}$

Sofoniasz zatem zapowiada zagładę Egiptu, jednak Izrael musi pamiętać, że już raz kiedyś, w czasach Dawida, miecz Pana zwrócił się przeciw Jego ludowi i świętemu miastu, Jeruzalem (zob. 2Sm 24,16-17). Czy zatem teraz nie powinni być na tyle przezorni, aby zauważyć zagrożenie dla siebie w wyciągniętym przeciw Kuszytom mieczu Pana?

${ }^{100}$ S. P o t o c k i, Księga Sofoniasza, s. 179.

${ }^{101}$ O.P. R o b e r t s o n, The Books of Nahum, Habakkuk and Zephaniah, s. 310.

${ }^{102}$ L. W a 1 k e r, Zephaniah, s. 555.

${ }^{103} N \bar{o}^{\prime}$-'àmôn, to inna nazwa Teb, stolicy Górnego Egiptu; nawiązywała ona do czczonego tam bóstwa; zob. komentarz do Na 3,8 w: Pismo Święte Starego Testamentu. Przekład Ekumeniczny, t. 3: Księgi prorockie, Warszawa 2016.

${ }^{104}$ R.A. B e n n e t t, The Book of Zephaniah, s. 691. 


\section{Wyrocznia przeciw Asyrii (So 2,13-15)}

Ostatnim z sąsiadów, przeciw któremu Sofoniasz wygłasza wyrocznię, jest Asyria, największy spośród wrogów Judy. Potęga imperium została osłabiona w czaszach Jozjasza, jednak nadal posiadało ono wystarczającą siłę dla sprowadzenia na Judę zagłady. Treścią tej wyroczni jest ogólna zapowiedź zagłady Asyrii i szczegółowy opis zniszczenia Niniwy. Do odnotowania jest również fakt, że o ile opis zagłady jest dość obszerny, o tyle uzasadnienie jest dość zdawkowe: „Oto zarozumiałe miasto, które czuje się bezpieczne i mówi w swoim sercu: Ja i nikt więcej” (w. 15).

\section{Dane geograficzne}

Asyria ('ššûr), dokładniej rzecz biorąc 'Aššûur, to nazwa zarówno miasto leżącego w północnej części biegu rzeki Tygrys, jak i całej krainy, której stolicą było wyżej wymienione miasto (a następnie Niniwa). Jest to również imię bóstwa wyznawanego w Asyrii. Pierwotnie nazwa określała miasto i imię boga; naród zaczęła określać między 1500 a 900 r. przed Chr., gdy miasto stało się państwem. $.^{105} \mathrm{Za}-$ tem ok. 1300 r. przed Chr. Asyria dobyła pozycję imperium na terenie „żyznego półksiężyca”. Około 1100 r. przed Chr. Tiglat-Pileser I rozciągnął swoje panowanie aż po wybrzeże Morza Śródziemnego, wówczas również podbite zostało królestwo Babilonii. Po osłabieniu wpływów w XI i X w. przed Chr., od IX w. przed Chr., za panowania Assurbanipala II (883-859 przed Chr.) i Salmanassara III (858-824 przed Chr.), rozpoczęła się ponowna ekspansja imperium. ${ }^{106} \mathrm{Na}$ ten okres przypada w 721 r. zdobycie Izraela, państwa północnego i zburzenie Samarii, jego stolicy. W VII w. przed Chr. pod naporem

105 P.B. M a ch in is t, Aszszur, tłum. M. Woj c i e chow s k i, w: P.J. A ch t e m e i r (red.), Encyklopedia Biblijna, s. 68.

${ }^{106}$ M. Er n s t, Babilonia i Asyria, tłum. M. S z c z e p a n i a k, w: F. K o g l e r, R. Eg g e r - W e n z e 1, M. E r n s, H. W i t c z y k (red.), Nowy Leksykon Biblijny, S. 54. 
imperium neobabilońskiego Asyria słabła, by w 605 r. przed Chr. ostatecznie przestać istnieć. Jej ziemie, jak i panowanie w dorzeczu Eufratu i Tygrysu, przejęła Babilonia. W ten sposób spełniły się zapowiedzi wielu proroków, którzy w bardzo zdecydowanych słowach występowali przeciw Asyrii, a szczególnie przeciw Niniwie (zob. np. Iz 10,5-13; 14,25; 30,27-33; 31,4-9; Mi 5,4-5; So 2,13). Duma Asyrii i jej królów została ukarana (Iz 10,12; Za 10,11), jej oddziały zostały wtrącone do szeolu (Ez 32,21-22). ${ }^{107}$

Niniwa (nînwēh), to jedno z najstarszych i największych miast Mezopotamii. Było położone na wschodnim brzegu Tygrysu, naprzeciw dzisiejszego Mosulu (Irak). Zostało zasiedlone ok. 5400 r. przed Chr., a w czasach Hammurabiego (1792-1750 przed Chr.), władcy imperium starobabilońskiego, zbudowano w nim świątynię bogini Isztar. ${ }^{108}$ Znaczenie miasta zaczęło szybko rosnąć od czasów Salmanassara I (1274-1245 przed Chr.); w tym również czasie stało się ono stolicą imperium asyryjskiego. Niniwa została rozbudowana i ufortyfikowana, zaczęła zyskiwać przewagę nad starszym Aszszur. Jej rola znacząco wzrosła zwłaszcza od czasów Assurbanipala II (884-854 przed Chr.) i jego następcy, Salmanassara III (859-823 przed Chr.). Za panowania Sennacheryba (704-681 przed Chr.) Niniwa stała się wielkim miastem (2Krl 19,36; Jon 1,2) o długości 27 km i szerokości ponad 16 km. Miała wspaniałe pałace, świątynię i zikkurat bogini Isztar. ${ }^{109} \mathrm{~W} 612$ r. miasto zostało zdobyte i zniszczone przez Medów i Babilończyków i od tego czasu stało się symbolem ostatecznej zagłady Asyrii. Pierwsza wzmianka o Niniwie w Biblii, to tzw. tablica narodów ( $\mathrm{Rdz} 10,11)$. Jej imię pojawia się także w związku ze wzmianką o zamordowaniu Sennacheryba (2Krl 19,36; Iz 37,37). Zagładę Niniwy zapowiadał zwłaszcza prorok Nahum ( $\mathrm{Na}$ 2,4-3,19). Z Niniwą związana jest

${ }^{107}$ P.C. B o s a k, Leksykon wszystkich miejsc biblijnych, s. 95.

${ }^{108}$ M. Er n s t, Niniwa, tłum. T. S i e m i en i e c, w: F. K o gle r, R. Eg g e r- W e n z e 1, M. E r n s, H. W i t c z y k (red.), Nowy Leksykon Biblijny, s. 528.

109 P.C. B o s a k, Leksykon wszystkich miejsc biblijnych, s. 648. 
szczególnie Księga Jonasza, jednak wzmianki o tym mieście mają W niej charakter raczej teologiczny niż historyczny. ${ }^{110}$

Treść i znaczenie wyroczni przeciw Asyrii

Wyrocznie przeciw obcym narodom w Księdze Sofoniasza osiągają swój punkt kulminacyjny w zapowiedzi zagłady Asyrii, imperium położonego na terenach północnych. Wyrocznię otwiera sekwencja działań (w. 13), które podejmie Bóg: ,i wyciągnie” (wejett), „i zniszczy” (wij’abèd), „i zmieni” (wejāśém). Tylko pierwsze z nich odnosi się do Asyrii. Zaskakuje dość zdawkowa treść tej części wyroczni. Sofoniasz koncentruje się na geście wyciągniętej przez Boga ręki (por. 1,4) w celu zniszczenia Asyrii (por. w. 5; Pwt 11,4; Ps 5,6; 21,10; Iz 26,14). ${ }^{111}$

Kolejne dwa działania będę skierowane przeciw Niniwie. Zapowiedź zniszczenia (wij’abēd) Niniwy, miasta, które rządziło ówczesnym światem (por. Jon 1,2; 3,3), wskazuje na to, że będzie to rzeczywiście dzieło samego Boga. Zmiana ( $\left.w^{e} j a \bar{s} s e-m\right)$ miasta w suchy step (por. Ps 63,1; Jr 2,6; 50,12; 51,43; J1 2,20) jest tym bardziej wymowna, bowiem Niniwa była znana ze swojego sytemu nawodnienia. ${ }^{12}$ W największym mieście tamtego regionu, a może nawet całego ówczesnego świata, nie znajdzie się nawet mała reszta mieszkańców, aby spowodować przetrwanie jego istnienia. I rzeczywiście, ok. $401 \mathrm{r}$. przed Chr. Ksenofont przeszedł przez teren Niniwy i nie znalazł śladów jej istnienia pośród niesionych wiatrem pisaków pustyni. Tak więc wyrocznia przeciw miastu znalazła swe dosłowne spełnienie. ${ }^{113}$

Sofoniasz kontynuuje opis spustoszenia Niniwy (w. 14), które podkreśla przez wyliczenie niektórych „mieszkańców” miasta. Są wśród nich „stada hodowlane” ('ädārîm; por. Rdz 32,19; Ps 78,52; Iz 40,11)

110 D.L. C h rist e n s e n, Niniwa, tłum. T. Mi e s z k ow s k i, w: P.J. A c h t em e i e r (red.), Encyklopedia Biblijna, s. 839.

111 D.W. B a k e r, Nahum, Habakkuk and Zephaniah, s. 107.

112 L. Wa 1 ke r, Zephaniah, s. 56.

113 O.P. R o b e r t s o n, The Books of Nahum, Habakkuk and Zephaniah, s. 312. 
i „dzikie zwierzęta” (kôl-hjetô-gôj). Oba określenia opisują, jak się wydaje, całą faunę, zarówno domową, jak i dziką (por. Rdz 1,24; Ps 50,10). ${ }^{114}$ Tak więc, zamiast żołnierzy maszerujących i zamożnej ludności prorok przewidział, że stada owiec i kóz oraz wszelkiego rodzaju stworzenia znajdą się w Niniwie (por. w. 6). Bogate i sławne miasto stało się odpowiednie tylko dla stad i dzikich zwierząt. „Pelikan" (qāa'at) i ,jeż” (qippōd) zostały przywołane w Izajaszowym opisie spustoszenia Edomu (zob. Iz 34,11). ${ }^{115}$ Tam jednak pojawiają się jeszcze „sowa” (janšûf) i „kruk” ('ōrēb), których obecność w tekście Sofoniasza nie jest w pełni udokumentowana. W każdym razie obecność tych nieczystych zwierząt wskazuje na brak mieszkańców ludzkich (por. Iz 14,23, 34,11). ${ }^{116}$ Niegdyś wspaniałe budynki Niniwy, rozbite w gruzy, stały się domami dla różnych stworzeń, które nie tylko zamieszkują odludne miejsca, lecz także sprawiają, że ziemia staje się nieczysta. W drzwiach pojawiły się tylko złowieszcze dźwięki. Okna i progi drzwi będą nosiły znaki opuszczenia. W starożytności pojęciem sap nazywano nie tylko „drzwi”, jako takie, lecz także tych, którzy trzymali tam straż w dzień i w nocy $(2 \mathrm{Krl} 22,4$; 23,4; 1Krn 9,19; Est 6,2; Jr 35,4). Teraz gruz leży u progu domu, a belki cedrowe ścian lub sufitów zostały obnażone z powodu zniszczenia. A trzeba zaznaczyć, że cedr jako materiał budowlany był niezwykle ceniony i drogi. Dawid i Salomon mieszkali w pałacach cedrowych ( $2 \mathrm{Sm} 7,2.7 ; 1 \mathrm{Krl} 5,6.8$ ). Szalum, syn Jozjasza, został bardzo surowo oceniony za marnowanie tego materiału na budowę swojego pałacu (Jr 22,14-16). Te luksusy nie będą już więcej udziałem mieszkańców Niniwy, belki cedrowe będę narażone na całkowite zniszczenie. ${ }^{117}$ Ten rodzaj zniszczenia w opisach biblijnych jest częsty dla tych, którzy sprzeciwiają się Bogu (Iz 13,19-22; 34,11-15; Jr 50,39).

Wyrocznia przeciw Asyrii zyskała swoje uzasadnienie w arogancji wobec Boga i daje teologiczne podstawy do usunięcie wszelkich

114 D.W. B a k e r, Nahum, Habakkuk and Zephaniah, s. 108.

${ }^{115}$ L. W a 1 ke r, Zephaniah, 56.

116 D.W. B a k e r, Nahum, Habakkuk and Zephaniah, s. 108.

117 O.P. R o b e r t s o n, The Books of Nahum, Habakkuk and Zephaniah, s. 313. 
aspektów asyryjskiego panowania w kraju (w. 15). Trzy cechy charakteryzowały Niniwę przed jej zniszczeniem: „zarozumiałość” ('alliz;; por. Iz 22,2; 23,7; 24,8; 32,13), „bezpieczeństwo” (hajjôšebet lābețah; dosł. „mieszkające bezpiecznie”; por. Kpł 25,18; 26,5; Pwt 12,10) i przekonanie o samowystarczalności (por. Iz 47,8.10). ${ }^{118}$ Uzasadnienie upadku miasta stanowi rozszerzone stwierdzenie dotyczące dumy Asyrii, która polegała na wywyższaniu się ponad Boga: „Oto zarozumiałe miasto, które czuje się bezpieczne i mówi w swoim sercu: Ja i nikt więcej!” (w. 15a). W tej wypowiedzi może pobrzmiewać to, co zostało zapisane na temat mieszkańców Jerozolimy, którzy mówią w swoich sercach: „Pan nie czyni nic dobrego ani złego” (So 1,12). ${ }^{119}$ Zatem powodem upadku tego „zarozumiałego” (por. 3,11; Iz 22,2; 23,7) i „bezpiecznego" miasta (por. 3,2; Kpł 25,18-19; Iz 47,8; Jr 23,6; Za 14,11) była jego arogancka duma, w której jego mieszkańcy myśleli o sobie (por. 1,12), że nie ma im równych (Iz 47,8.10; Za 3,11). To przekonanie o samowystarczalności i niepowtarzalności sprawiła, że Asyria stanęła w zasadniczej opozycji wobec Dekalogu (Wj 20,3), a w którym zawarty był nakaz: „Nie będziesz miał cudzych bogów obok Mnie!". Niniwa uzurpowała sobie tę władzę, stawiając siebie $\mathrm{w}$ miejsce Jedynego Boga. ${ }^{120} \mathrm{Z}$ tego właśnie powodu Niniwa zostanie zgładzona. Zarozumiałe i bezpieczne miasto chciało się pochwalić swoją samowystarczalnością (,,ja i nikt więcej”; 'ănî we'afesî 'ôd 'êk), jednak w swojej wizji prorockiej Sofoniasz przewidział, że stanie się ono pustkowiem (por. 1,13; 2,4.9.13; Iz 5,9; Mi 6,16) i siedliskiem dzikich zwierząt (por. w. 14; Ez 25,5). Ta sama zasada wykazania samowystarczalności dotyczyła Babilonii (Iz 47,8) i Laodycei (Ap 3,17). Sofoniasz przyłącza się do współczesnego sobie Nahuma, który tak przewiduje koniec Niniwy: „będą klaskać w dłonie nad tobą” (tāq $q^{e} \hat{o}$ kaf 'àlêkā; Na 3,19). ${ }^{121}$ On jednak pisze: „Każdy przechodzący za-

118 S. P o t o c k i, Księga Sofoniasza, s. 183.

119 R.A. B e n n e t t, The Book of Zephaniah, s. 691; O.P. R o b e r t s o n, The Books of Nahum, Habakkuk and Zephaniah, s. 313.

${ }^{120}$ D.W. B a k e r, Nahum, Habakkuk and Zephaniah, s. 109.

${ }^{121}$ L. Wa $1 \mathrm{ke} \mathrm{r,} \mathrm{Zephaniah,} \mathrm{s.} \mathrm{555-556.}$ 
gwiżdże i machnie ręką" (w. 15c). Wzmianka o dłoni (jād) może być swoistą inkluzją. Na początku wyroczni przeciw Asyrii mowa

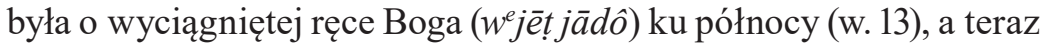
czytamy o machaniu ręką $\left(j \bar{a} n \imath^{a{ }^{a}} j \bar{a} d \hat{o}\right)$ przez przechodzących (w. 15). ${ }^{122}$ W ten sposób wyrocznia przeciw obcym narodom zyskuje znaczenie przekleństwa dla nich, a błogosławieństwa dla ludu Bożego. ${ }^{123}$

$$
* * *
$$

Wyrocznie przeciw obcym narodom w Księdze Sofoniasza (So 2,4-15) zostały skierowane przeciw Filistynom, Ammmonitom i Moabitom, Egipcjanom oraz Asyrii. Ich porządek nie jest do końca jasny, i jest trudny, jeśli w ogóle możliwy, do wyjaśnienia.

Sposób przedstawienia wyroczni przeciw Filistynom (So 2,4-7) opiera się na wielości nazw miast, które należały do tej części Palestyny. Słowa skierowane przeciw nim, ,zniszczę cię, pozbawię mieszkańców" (So 2,5), każą Judejczykom podjąć refleksję nad własnym postępowaniem, które mogło sprowokować zniszczenie ich, tak jak teraz zniszczone zostaną obce narody. Wyniszczenie Filistynów ma być dla Judejczyków przestrogą przed czekającą ich karą, jeśli nie zmienią swojego postępowania.

Wyrocznia przeciw Moabitom i Ammonitom (2,8-11) zaskakuje dwoma sprawami. Po pierwsze, rzecz dotyczy określenia kōl 'ijjê haggôjim (So 2,11), które może odnosić się albo do wszystkich narodów w ogólności, albo tych narodów, które są wrogie wobec Izraela. W bezpośrednim kontekście poprzedzającym Sofoniasz pisał na temat zwycięstwa JHWH nad bóstwami pogańskimi (w. 11a), należy zatem przypuszczać, że to przedstawiciele nawet najodleglejszych zakątków ziemi oddadzą cześć JHWH. Po drugie, nieco zaskakujące jest odwrócenie normalnego porządku w wyroczniach przeciw narodom, w których zwykle najpierw podane zostało uzasadnienie, a następnie kara, gdy tymczasem Sofoniasz najpierw podał karę

${ }^{122}$ D.W. B a k e r, Nahum, Habakkuk and Zephaniah, s. 109.

${ }^{123}$ R.A. B e n n e t t, The Book of Zephaniah, s. 691. 
(ww. 8 i 10), a dopiero później uzasadnienie (ww. 9 i 11a). Dlaczego prorok tak właśnie skonstruował tę wyrocznię? Przede wszystkim mogło chodzić o emfazę, z jaką Sofoniasz podkreśla powód (uzasadnienie) kary spadającej na Moabitów i Ammonitów. Należy jednak zwrócić uwagę również na w. 11b, który zawiera eschatologiczną zapowiedź powszechnego kultu JHWH. Mogło więc chodzić o to, aby w formie klimaktycznej doprowadzić wypowiedź wyroczni właśnie do tego eschatologicznego orędzia.

Słowa skierowane przeciw Egiptowi (So 2,12) są tak zdawkowe, że niektórzy uczeni uznali je za część wyroczni przeciw Asyrii. Jednak wydaje się, że takie połączenie byłoby całkowicie nieuzasadnione, choćby dlatego, że kara, jaka spotka Kuszytów i Asyryjczyków, jest odmienna, nie mówiąc już o tym, że imperia Asyrii i Egiptu były odwiecznymi, lecz różnymi wrogami Izraela. Miecz wyciągnięty przeciw Egiptowi (So 2,12) stanowi niewątpliwie aluzję do sceny, która rozegrała się u bram Jerycha, kiedy to Jozue spotkał anioła Pańskiego z obnażonym mieczem (Joz 5,13).

Opis zagłady Asyrii (So 2,13-14) jest bardzo obszerny, ponieważ w nim wyrocznie przeciw obcym narodom w Księdze Sofoniasza osiągają swój punkt kulminacyjny. Uzasadnienie zaś wydaje się wręcz zdawkowe (w. 15) wobec bezmiaru kary.

ks. Stawomir STASIAK

Słowa kluczowe: Księga Sofoniasza, Filistyni, Moabici, Ammonici, Kuszyci, Egipt, Asyria, wyrocznie przeciw narodom

Keywords: Book of Zephaniah, Philistines, Moabites, Ammonites, Kushim, Egypt, Assyria, Oracles against the Nations 


\section{Foreign Nations in the Book of Zephaniah}

Summary

The oracles against foreign nations in the Book of Zephaniah (Zeph 2:4-15) were directed against the Philistines, the Ammonites, the Moabites, the Egyptians and against the Assyrians. Their order is not quite clear, challenging, and wonder if it is really explicable to the very end.

The way the oracle is presented against the Philistines (Zeph 2:4-7) is based on the multitude of names of places, which belonged to this part of Palestine. The words directed against them "I will destroy you until no inhabitant is left" (Zeph 2:5), force the Judeans to reflect on their behavior, which could lead on to their annihilation, the way the foreign nations will be destroyed at this moment. The attrition of the Philistines is to function as a warning for the Judeans against the imminent and awaited punishment, unless they change their conduct.

The oracles against the Moabites and the Ammonites (2:8-11) bewilder in two aspects. First of all, the issue concerns the determination of kōl 'ijjê haggôjim (Zeph 2:11), which can either refer to all nations in general, or only to those nations which are hostile towards the Israel. In the direct, preceding context, Zephaniah was writing about the victory of JHWH over pagan gods (v. 11a); Thus, one may suppose that the representatives of even the remotest corners of the earth will pay homage to JHWH. Secondly, what is surprising is the reverse order, the reversal of the usual order in the oracles against the nations, in which the punishment is presented as first and then its justification. Whereas, Zephaniah starts with justification (v. 8 and 10), and later mentions the punishment (v. 9 and 11a). Why was the oracle constructed in this specific way by the prophet? First of all, it may have constituted an emphasis which Zephaniah uses to stress the cause (justification) of the punishment imposed on the Moabites and the Ammonites. However, attention must also be drawn to w. 11b, which contains eschatological announcement of the universal and widespread cult of JHWH. Thus, the expression of the oracle was meant to lead to eschatological proclamation, in an climactic construction.

The words directed against Egypt (Zeph 2:12) are so cursory that some scholars regard them as part of the oracle against Assyria. Yet, it seems that such a connection would be completely unjustifiable, merely because of the fact that the punishment the Nubians and the Assyrians will face will be different, not to mention the fact that the empires of Assyria and Egypt 
were immemorial enemies of Israel, but different, though. The sword taken out against Egypt (Zeph 2:12) undoubtedly, constitutes a kind of glancing reference to the scene which took place at the gates of Jericho, when Joshua encountered the Angel of God with an unsheathed sword (Jos 5:13).

The description of extermination and destruction of Assyria (Zeph 2:13-14) is comprehensive and extensive because the oracles against foreign nations in the Book of Zephaniah reach their climax there. Justification in this case seems to be perfunctory, though (v. 15) especially considering the immensity of the punishment. 